\title{
Development and function of trophoblast giant cells in the rodent placenta
}

\author{
DONG HU and JAMES C. CROSS* \\ Department of Comparative Biology \& Experimental Medicine, Faculty of Veterinary Medicine and \\ Graduate Program in Biochemistry \& Molecular Biology, University of Calgary, Calgary, Alberta, Canada
}

\begin{abstract}
Trophoblast giant cells (TGCs) are the first cell type to terminally differentiate during embryogenesis and are of vital importance for implantation and modulation of post-implantation placentation. TGCs are mononuclear and polyploid but are heterogenous and dynamic. At least four different subtypes of TGCs are present within the mature placenta that have distinct cell lineage origins. The development of TGCs is complex and requires transition from the mitotic to the endoreduplication cell cycle and is regulated by a wide variety of factors. During early gestation, TGCs mediate blastocyst attachment and invasion into the uterine epithelium, regulate uterus decidualization, and anatomosis with maternal blood spaces to form the transient yolk sac placenta. During later gestation, TGCs secrete a wide array of hormones and paracrine factors, including steroid hormones and Prolactin-related cytokines, to target the maternal physiological systems for proper maternal adaptations to pregnancy and the fetal-maternal interface to ensure vasculature remodeling. The large number of mouse mutants with defects in TGC development and function are giving us significant new insights into the biology of these fascinating cells.
\end{abstract}

KEY WORDS: pregnancy, hormone, cell cycle, polyploid, endoreduplication

\section{The enigmatic life of the trophoblast giant cell}

Trophoblast giant cells (TGCs) are the first terminally differentiated cell type to form during embryogenesis in rodents and are of vital importance for embryo implantation and promoting maternal adaptations to pregnancy. They arise from the trophectoderm layer in the blastocyst (Fig. 1), are endocrine in nature and characterized by their extremely large cytoplasm and polyploid nuclei that result from endoreduplication (Zybina and Zybina, 1996). TGCs are best studied in rodents and are usually mononucleated. In mice, there are several subtypes of TGCs with distinct functions that arise at different stages of gestation and in different locations within the placenta (Simmons et al., 2007; Simmons et al., 2008b). Mono-nucleated, bi-nucleated or occasionally multi-nucleated cells with polyploid nuclei have also been identified in the rabbit, vole, fox, human, cow, water buffalo and alpaca placenta (Carvalho et al., 2006; Klisch et al., 2005; Klisch et al., 1999; Klisch et al., 2004; Zybina et al., 1975; Zybina and Zybina, 1985; Zybina et al., 1992; Zybina et al., 2004; Zybina et al., 2002; Zybina et al., 2001). In humans, the polyploid cells are the so-called extravillous cytotrophoblast cells that invade into the uterus (Zybina et al., 2002) and are associated with remodeling of the spiral arteries (Pijnenborg et al., 1980). In addition to polyploidy, many genes that are involved in TGC development and function in rodents are conserved between rodents and humans, such as transcription factors, proteases and cell adhesion molecules (Cross et al., 2003; Rawn and Cross, 2008). Therefore, studies of TGCs should give insights into human gestational diseases that are associated with extravillous cytotrophoblast cells such as preeclampsia and intrauterine growth restriction (Brosens et al., 1977; Brosens et al., 1972). We review here the development and functions of TGCs focusing on insights from mice, discussing the differences between TGC subtypes and implications of their diverse functions.

\section{Characteristics, origins and regulation of TGC devel- opment}

The mature placenta in rodents is composed of three broad zones including the maternal decidua on the outside, the junc-

Abbreviations used in this paper: TGC, trophoblast giant cell; C-TGC, matrnal blood canal associate TGC; P-TGC, parietal TGC; SpA-TGC, spinal artery associated TGC.

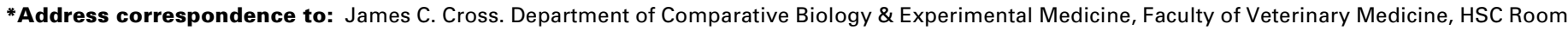
2279, University of Calgary, Calgary, Alberta, T2N 4N1, Canada. Fax: +1-403-270-0737. e-mail: jcross@ucalgary.ca
} 


\section{E3.5}

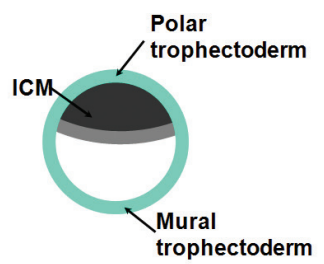

E7.5

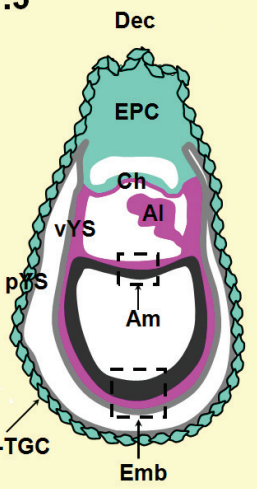

E12.5

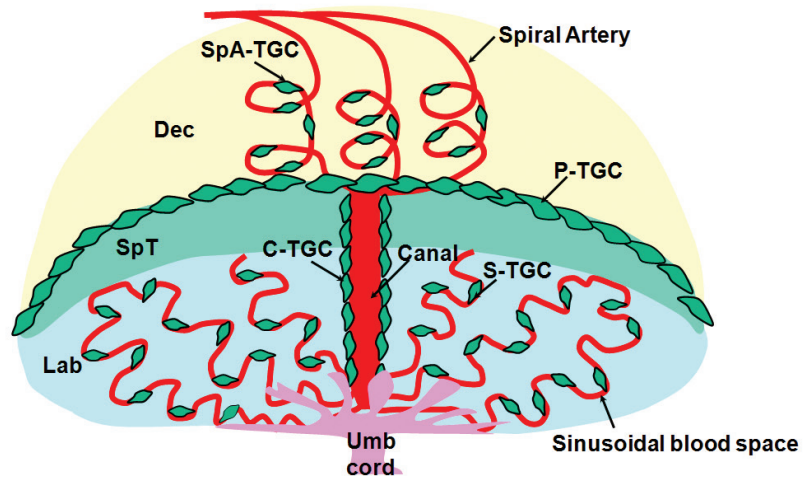

Fig. 1. Overview of placental structure in the mouse. Diagrams depict early development of the mouse conceptus at embryonic days (E) 3.5, 7.5 and 12.5, displaying the components of the mature placenta and different subtypes of TGCs. Abbreviations: Al, allantois; Am, amnion; Ch, chorion; Dec, decidua; Emb, embryo; Epc, ectoplacental cone; ICM, inner cell mass; Lab, Labyrinth; pYS, parietal yolk sac; SpT, spongiotrophoblast; TGC, trophoblast giant cell; Umb Cord, umbilical cord; vYS, visceral yolk sac. C-TGC, maternal blood canal trophoblast giant cell; P-TGC, parietal trophoblast giant cell; S-TGC, sinusoidal trophoblast giant cell; SpA-TGC, spiral artery-associated trophoblast giant cell; Cyan-trophectoderm and trophoblast lineage, Black-inner cell mass and embryonic ectoderm, Gray-endoderm, Red-maternal vasculature, Purple-mesoderm, Yellow-decidua, Pink-fetal blood vessels in labyrinth.

tional zone and the innermost labyrinth (Fig. 1). The decidua is devoid of trophoblast cells until around mid-gestation when trophoblast cells invade both into the decidua and up the spiral arteries, replacing the endothelium and thereby promoting the transition from endothelial cell-lined to trophoblast cell-lined maternal blood spaces (hemo-chorial) in the placenta (Adamson et al., 2002). The junctional zone consists of spongiotrophoblast cells and a layer of TGCs that line the implantation site. The labyrinth is the region in which nutrient exchange occurs and the bulk of the trophoblast compartment is composed of two layers of multi-nucleated syncytiotrophoblast that arise from cell-cell fusion of post-mitotic cells (Hernandez-Verdun and Legrand, 1975) and not endomitosis or endoreduplication as with TGCs. Four TGC subtypes have been identified in the placenta (Simmons et al., 2007), and include parietal TGC (P-TGC) that line the implantation site and are in direct contact with decidual and immune cells in the uterus, spiral artery-associated TGCs (SpA-TGC), maternal blood canal-associated TGCs (C-TGC), and sinusoidal TGC (S-TGC) that are within the sinusoidal blood spaces of the labyrinth (Figs. 1 and 2). The four subtypes of TGCs are distinguished by their anatomical location and gene expression (Table 1) (Simmons et al., 2007).

\section{Characteristics of TGCs}

All TGC subtypes share the characteristics that they are large, have polyploid (usually single) nuclei, and are secretory in nature with their content of golgi and endoplasmic reticulum increasing during differentiation (Bevilacqua and Abrahamsohn, 1988). In contrast to proliferating cells, TGCs undergo rounds of DNA replication without intervening mitoses, a process called endoreduplication, and can accumulate DNA up to 1000C (Zybina and Zybina, 1996). The genome of P-TGCs is 'polytene', a state in which many sister chromatids are synapsed together resulting from multiple rounds of genome replication (Varmuza et al., 1988; Zybina and Zybina, 1996). While the other subtypes of TGCs have polyploid nuclei (Simmons et al., 2007), it is unclear whether their nuclei are polytene. Consistent with their large cytoplasm and extensive rough endoplasmic reticulum, TGCs secrete a variety of proteins including extracellular matrix, cell adhesion molecules, proteinases, cytokines and hormones (see below).

The importance of endoreduplication and polyploidy for TGC function is a matter of speculation. Polyploid nuclei have been identified in many plant and animal cells with secretory or nutritive function such as salivary gland and follicle cells in Drosophila melanogaster, and leaf cells in plants (Edgar and Orr-Weaver, 2001). It has been suggested that polyploidy may increase their capacity for protein synthesis. Alternatively, since TGCs have a relatively short lifespan, it may be that endoreduplication and the associated cell hypertrophy allow tissue growth with less time and energy expenditure. An extension of this hypothesis is that because TGCs are post-mitotic, they function without risk of forming

TABLE 1

\section{CHARACTERISTICS AND FUNCTION OF THE FOUR DIFFERENT TGC SUBTYPES IN THE MATURE PLACENTA}

\begin{tabular}{|c|c|c|c|c|}
\hline Subtype & Location & Temporal appearance & Gene expression & Suggested function \\
\hline SpA-TGC & $\begin{array}{l}\text { Lining maternal spiral arteries bringing } \\
\text { blood into placenta }\end{array}$ & E10.5 & Plf & Regulate maternal spiral artery remodeling and blood flow into the placenta \\
\hline P-TGC & $\begin{array}{l}\text { Lining implantation site and outer layer of } \\
\text { parietal yolk sac }\end{array}$ & E7.5 & $P / 1, P / 2$, Plf & $\begin{array}{l}\text { Facilitate implantation and initial maternal vascular connections, regulate } \\
\text { decidual cell differentiation, and maternal physiology }\end{array}$ \\
\hline C-TGC & $\begin{array}{l}\text { Lining canals that bring maternal blood to } \\
\text { base of labyrinth }\end{array}$ & E10.5 & Plf, Pl2 & Regulate maternal vasculature remodeling and maternal physiology \\
\hline S-TGC & $\begin{array}{l}\text { Within maternal blood sinusoids of the } \\
\text { labyrinth layer }\end{array}$ & E10.5 & Ctsq, $P 12$ & $\begin{array}{l}\text { Modulation of hormone and growth factor activity before they enter fetal and/or } \\
\text { maternal circulation, regulate maternal physiology }\end{array}$ \\
\hline
\end{tabular}


tumours (Hemberger, 2008). This is important since TGCs have the ability to invade and promote local angiogenesis (see below). Interestingly though, TGC nuclei in voles become fragmented during late gestation with sex chromosomes in each sub-domain, and this suggests that there is some structural order to the polyploid nuclei (Zybina et al., 2005). The formal test of whether or not polyploidy is critical for function is to analyze mutants in which it does not occur. Endoreduplication is compromised in cyclin E1/ E2-deficient mice but markers of TGCs are still induced, indicating that endoreduplication and differentiation are not linked (Geng et al., 2003; Parisi et al., 2003).

\section{Transformation of the mitotic cell cycle to the endocycle in TGCs}

Mechanisms concerning the initiation and maintenance of endoreduplication have been well studied in flies and plants (Edgar and Orr-Weaver, 2001; Larkins etal., 2001), though there are some data from rodent TGCs as well (Fig. 3) (Hattori et al., 2000; MacAuley et al., 1998; Nakayama etal., 1998). The most obvious change in the cell cycle is that $S$ phase is dissociated from $M$ phase. This is not trivial since checkpoint controls normally prevent initiation of DNA replication until completion of mitosis and entry into mitosis is prevented until completion of S phase (Elledge, 1996). TGCs show other changes in checkpoint controls such that they continue through DNA replication even after sustaining DNA damage (MacAuley et al., 1998).

\section{The G2 decision point: mitosis or endoreduplication?}

In a mitotic cell cycle, cyclin B/Cdk1 promotes entry into mitosis (Sherr and Roberts, 2004). The Rcho-1 trophoblast cell line has been used to study TGC differentiation as precursor cells that have committed to leave the mitotic cell cycle can be selected as a result in a change in cell adhesiveness even before they have begun to endoreduplicate (MacAuley et al., 1998). The transition occurs in the $\mathrm{G} 2$ phase but cyclin B/Cdk1 complex is not activated due to reduced association of cyclin $B$ and Cdk1 (MacAuley et al., 1998). This is likely due to the effect of the Cdk inhibitor p57Kip2 which has recently been shown to inhibit Cdk1 activity during TGC differentiation (Ullah et al., 2008). In the subsequent endocycle, cyclin B expression is suppressed (MacAuley et al., 1998; Palazon et al., 1998). The zinc finger transcription factor Snail regulates the 'G2 decision point' of whether trophoblast cells go through mitosis or enter the endocycle (Fig. 3) (Nakayama et al., 1998). Its precise mechanism is unknown but over-expression of Snail increases expression of the mitotic cyclins A and B (Nakayama et al., 1998).

\section{Resetting the periodic $S$ phases during endoreduplication}

During the mitotic cell cycle, biochemical events coincident with mitosis lead to the re-setting of the

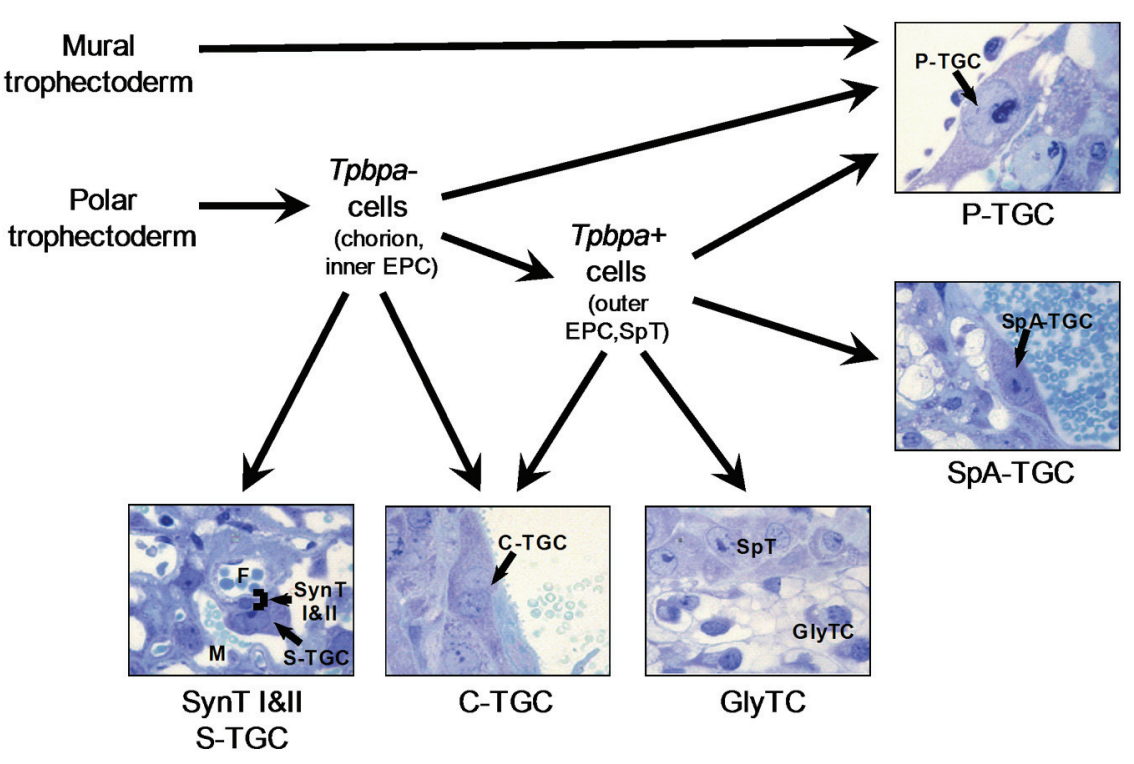

Fig. 2. Outline of the trophoblast cell lineage and origins of different TGC subtypes. Micrographs of different trophoblast cell subtypes show high magnification views of toluidine blue-stained plastic sections of the mid-gestation placenta. C-TGC, canal tropholast giant cell; EPC, ectoplacental cone; F, fetal capillary; GlyTC, glycogen trophoblast cell; M, maternal sinusoid blood space; P-TGC, parietal trophoblast giant cell; S-TGC, sinusoidal trophoblast giant cell; SpA-TGC, spiral artery-associated trophoblast giant cell; SpT, spongiotrophoblast; SynT-I \& II, syncytiotrophoblast cell layers I and II.

origins of replication (Elledge, 1996). This includes degradation of the protein Geminin which otherwise suppresses the firing of origins of replication (McGarry and Kirschner, 1998). Geminin mutant embryos die during pre-implantation development and show ectopic endoreduplication in blastomeres (Gonzalez et al., 2006). Another important mechanism to maintain periodicity during the endocycle involves cyclic expression of p57 Kip2, a G1/S Cdk inhibitor (Hattori etal., 2000). When TGC differentiation is initiated, p5 7 Kip2 $\mathrm{mRNA}$ expression appears during the transition endocycle (Fig. 3) (Hattori et al., 2000). During subsequent endocycles, p57 Kip2 protein levels fluctuate and this defines two phases: a

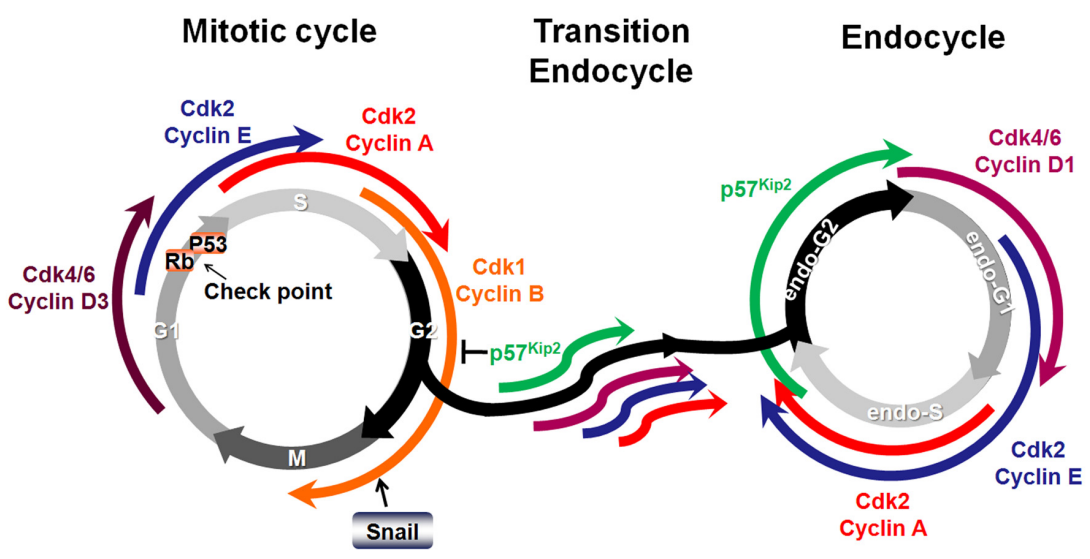

Fig. 3. Overview of the expression and activity of cell cycle regulators that function during the transition from the mitotic cell cycle to the endocycle associated with TGC differentiation based on published data (Hattori et al., 2000; MacAuley et al., 1998; Nakayama et al., 1998; Ullah et al., 2008). 
TABLE 2

\section{GENES REGULATING TGC DEVELOPMENT}

\begin{tabular}{|c|c|c|c|}
\hline Name & Gene product & Function & Reference \\
\hline \multicolumn{4}{|c|}{ Trophoblast stem cell specification and maintenance } \\
\hline Eomes & T-box transcription factor & Mutants die at peri-implantation stage, primary TGCs absent & (Russ et al., 2000) \\
\hline Elf5 & Ets transcription factor & $\begin{array}{l}\text { Mutants die by E } 8.5 \text { with extraembryonic ectoderm absent, } \\
\text { ectoplacental cone present }\end{array}$ & (Donnison et al., 2005) \\
\hline Err2/Err $\beta$ & Orphan nuclear receptor & Mutants die by E9.5 with chorion absent, TGC number increased & (Luo et al., 1997, Tremblay et al., 2001a) \\
\hline Foxd3 & Forkhead transcription factor & Mutants ie by E6.5 with TGC number increased & (Tompers et al., 2005) \\
\hline$A P-2 \gamma$ & AP-2 family of transcription factors & $\begin{array}{l}\text { Mutants die by E8.5 with trophoblast stem cells and ectoplacental cone } \\
\text { reduced, Primary TGCs reduced }\end{array}$ & (Auman et al., 2002, Werling and Schorle, 2002) \\
\hline Erf & Ets domain transcriptional repressor & $\begin{array}{l}\text { Mutants die by } 10.5 \text { with persistence of ectoplacental cavity, failure in } \\
\text { chorioallantoic attachement, expanded TGCs layer }\end{array}$ & (Papadaki et al., 2007) \\
\hline Ets2 & Ets transcription factor & $\begin{array}{l}\text { Mutants die by E8.5 with chorion absent and ectoplacental cone growth } \\
\text { reduced and defective trophoblast stem cells self renewal }\end{array}$ & (Yamamoto et al., 1998, Wen et al., 2007) \\
\hline$D p 1$ & DP family transcription factor & $\begin{array}{l}\text { Mutants die by E12.5 with reduced chorion, fewer TGCs and TGCs with } \\
\text { minimal nuclear enlargement }\end{array}$ & (Kohn et al., 2003) \\
\hline FGF4 & Fibroblast growth factor & $\begin{array}{l}\text { Mutants die shortly after implantation with failure to maintain trophoblast } \\
\text { stem cells, premature TGC formation }\end{array}$ & (Feldman et al., 1995, Tanaka et al., 1998) \\
\hline FGFR2 & Fibroblast growth factor receptor 2 & $\begin{array}{l}\text { Mutants die shortly after implantation with failure to maintain trophoblast } \\
\text { stem cells, premature TGC formation }\end{array}$ & (Arman et al., 1998) \\
\hline Erk2 & Extracellular signal-regulated kinase 2 & $\begin{array}{l}\text { Mutants die shortly after implantation, extraembryonic ectoderm and } \\
\text { ectoplacental cone not formed }\end{array}$ & (Hatano et al., 2003, Saba-El-Leil et al., 2003) \\
\hline Shp2 & Non-receptor protein-tyrosine phosphatase & $\begin{array}{l}\text { Mutants die at peri-implantation stage, trophoblast stem cells not } \\
\text { generated }\end{array}$ & (Yang et al., 2006) \\
\hline Nodal & $\begin{array}{l}\text { Transforming growth factor } \beta \text { superfamily } \\
\text { member }\end{array}$ & $\begin{array}{l}\text { Mutants die by E9.5 with spongiotrophoblast layer reduced and TGC } \\
\text { number increased }\end{array}$ & (Guzman-Ayala et al., 2004, Ma et al., 2001) \\
\hline Activin & $\begin{array}{l}\text { Transforming growth factor } \beta \text { superfamily } \\
\text { member }\end{array}$ & Promotes maintenance of cultured trophoblast stem cells & (Erlebacher et al., 2004) \\
\hline $\operatorname{Tgf} \beta$ & $\begin{array}{l}\text { Transforming growth factor } \beta \text { superfamily } \\
\text { member }\end{array}$ & Promotes maintenance of cultured trophoblast stem cells & (Erlebacher et al., 2004) \\
\hline$B M P 2$ & $\begin{array}{l}\text { Transforming growth factor } \beta \text { superfamily } \\
\text { member }\end{array}$ & $\begin{array}{l}\text { Mutants die by around E8.5 with amnion/chorion defects caused by an } \\
\text { open proamniotic canal }\end{array}$ & (Zhang and Bradley, 1996) \\
\hline Acvr1b & Activin/Nodal receptor 1B & Mutants die by E9.5 with disorganized extraembryonic ectoderm & (Gu et al., 1998) \\
\hline Acvr2, Acvr2b & Activin/Nodal receptor 2 and $2 \mathrm{~B}$ & Compound homozygous mutants die by E8.5 & (Song et al., 1999) \\
\hline Smad1 & Intracellular transducer of TGF- $\beta$ signals & $\begin{array}{l}\text { Mutants die by E10.5 with chorion erratically folded and allantois growth } \\
\text { defects }\end{array}$ & $\begin{array}{l}\text { (Arnold et al., 2006, Lechleider et al., 2001, } \\
\text { Tremblay et al., 2001b) }\end{array}$ \\
\hline mTOR & Mammalian TOR (target of rapamycin) & $\begin{array}{l}\text { Mutants die shortly after implantation. Mutant trophoblast fails to } \\
\text { proliferate in vitro. }\end{array}$ & (Murakami et al., 2004) \\
\hline \multicolumn{4}{|c|}{ Ectoplacental cone and spongiotrophoblast maintenance } \\
\hline Mash2 & Basic helix-loop-helix transcription factor & $\begin{array}{l}\text { Mutants die by E10 with smaller ectoplacental cone and lack of } \\
\text { spongiotrophoblast, TGC number increased, labyrinth layer reduced }\end{array}$ & $\begin{array}{l}\text { (Guillemot et al., 1994, Scott et al., 2000, Tanaka et } \\
\text { al., 1997) }\end{array}$ \\
\hline Sp1,3 & Zinc finger transcription factors & $\begin{array}{l}\text { Sp1-/- die by E10.5, Sp3-/- die postnatally, spongiotrophoblast layer } \\
\text { decreased in Sp1/Sp3 compound heterozygous and Sp3-/- mutants }\end{array}$ & (Kruger et al., 2007) \\
\hline$P P A R \beta / \delta$ & $\begin{array}{l}\text { nuclear receptor peroxisome proliferator- } \\
\text { activated receptor } \beta / \delta \text {; lipid-activated } \\
\text { transcription factors }\end{array}$ & Mutants die by E10.5 with reduced spongiotrophoblast and TGC & (Nadra et al., 2006, Wang et al., 2007) \\
\hline HIF & $\begin{array}{l}\text { bHLH/PAS transcription factors composed of } \\
\text { HIF } \alpha \text { and HIF } \beta / \text { Arnt subunits }\end{array}$ & $\begin{array}{l}\text { Arnt }{ }^{/-} \text {and } \mathrm{Hif}_{1} \alpha^{-/} \text {Hif } 2 \alpha^{-/-} \text {die by E10.5 with TGC number increased, } \\
\text { smaller ectoplacental cone and reduced spongiotrophoblast }\end{array}$ & $\begin{array}{l}\text { (Abbott and Buckalew, 2000, Adelman et al., 2000, } \\
\text { Cowden Dahl et al., 2005) }\end{array}$ \\
\hline Cited 1 & CBP/p300-interacting transactivator & $\begin{array}{l}\text { Mutants die shortly after birth, spongiotrophoblast layer irregular in } \\
\text { shape and enlarged }\end{array}$ & (Rodriguez et al., 2004) \\
\hline Cited 2 & CBP/p300-interacting transactivator & $\begin{array}{l}\text { Mutants die by E14.5 with reduced spongiotrophoblast, glycogen } \\
\text { trophoblast cells and TGCs }\end{array}$ & (Withington et al., 2006) \\
\hline Dnmt3L & DNA methyltransferase 3-like protein & $\begin{array}{l}\text { Mutants die by E10.5 with TGCs number increased, spongiotrophoblast } \\
\text { and labyrinth reduced }\end{array}$ & (Arima et al., 2006) \\
\hline Keratin 8, 18, 19 & Cytokeratin-intermediate filaments & $\begin{array}{l}\text { K8-/- die by E12.5, K8-/-K19-/- die by E10.5 and K18-/-K19-/- die by } \\
\text { E9.5, all with altered TGCs }\end{array}$ & $\begin{array}{l}\text { (Hesse et al., 2000, Jaquemar et al., 2003, Tamai et } \\
\text { al., 2000) }\end{array}$ \\
\hline Connexin 31 & Connexin; Gap junction protein & $\begin{array}{l}60 \% \text { mutants die between E10.5 and } 13.5 \text { TGC number increased, } \\
\text { spongiotrophoblast and labyrinth decreased }\end{array}$ & (Kibschull et al., 2004, Plum et al., 2001) \\
\hline Connexin 31.1 & Connexin; Gap junction protein & $\begin{array}{l}\text { Mutants die by E14.5, compact spongiotrophoblast with increased } \\
\text { thickness }\end{array}$ & (Zheng-Fischhofer et al., 2007) \\
\hline Bruce & $\begin{array}{l}\text { BIR repeat-containing ubiquitin-conjugating } \\
\text { enzyme }\end{array}$ & $\begin{array}{l}\text { Mutants in C57BL/ } 6 \text { background die perinatally with spongiotrophoblast } \\
\text { reduced }\end{array}$ & (Hitz et al., 2005, Lotz et al., 2004) \\
\hline HOP/NECC1 & $\begin{array}{l}\text { Homeodomain-only protein/not expressed in } \\
\text { choriocarcinoma clone } 1 \text { (HOP/NECC } 1 \text { ) }\end{array}$ & Mutants have TGCs number increased, spongiotrophoblast reduced & (Asanoma et al., 2007) \\
\hline Talin & $\begin{array}{l}\text { Cytoplasmic protein associated with integrin- } \\
\text { containing cellular junctions }\end{array}$ & $\begin{array}{l}\text { Mutants die by E9.5 with disorganized extraembryonic tissues and the } \\
\text { ectoplacental and excocoelomic cavities are not formed }\end{array}$ & (Monkley et al., 2000) \\
\hline \multicolumn{4}{|c|}{ TGC terminal differentiation } \\
\hline Hand1 & Basic helix-loop-helix transcription factor & $\begin{array}{l}\text { Mutants die by E } 8.5 \text { with smaller ectoplacental cone, TGC number } \\
\text { reduced and nuclear size reduced }\end{array}$ & $\begin{array}{l}\text { (Firulli et al., 1998, Riley et al., 1998, Scott et al., } \\
2000 \text { ) }\end{array}$ \\
\hline Stra13 & Basic helix-loop-helix transcription factor & Over-expression stimulates TGC differentiation & (Hughes et al., 2004) \\
\hline
\end{tabular}


TABLE 2 (CONTINUED)

\begin{tabular}{|c|c|c|c|}
\hline I-mfa & bHLH transcription factor repressor protein & $\begin{array}{l}\text { Mutants die by E10.5 in C57B1/6 background } \\
\text { TGC number reduced }\end{array}$ & (Kraut et al., 1998) \\
\hline Eed & Polycomb group protein & $\begin{array}{l}\text { Mutants die by E11.5 with TGC number reduced, TGC nuclear size } \\
\text { preferentially small in females }\end{array}$ & (Wang et al., 2001) \\
\hline Snail & $\begin{array}{l}\text { Zinc finger transcription } \\
\text { factor }\end{array}$ & Over-expression suppresses TGC differentiation & (Nakayama et al., 1998) \\
\hline Gata2,3 & $\begin{array}{l}\text { Zinc finger transcription } \\
\text { factor }\end{array}$ & $\begin{array}{l}\text { Gata2 -/- die by E10 and Gata3-/- die by E11.5, TGCs with reduced } \\
\text { hormone synthesis and indistinguishable cell number }\end{array}$ & (Ma and Linzer, 2000, Ma et al., 1997) \\
\hline Sox15 & Sry-type HMG box (Sox) transcription factor & Ectopic expression of Sox15 promotes TGC differentiation & (Yamada et al., 2006) \\
\hline LIF & Leukemia inhibitory factor & $\begin{array}{l}\text { Administration promotes TGC differentiation in vitro and in vivo, genetic } \\
\text { reduction in LIF rescues TGC phenotype in Socs } 3 \text { null mutants }\end{array}$ & $\begin{array}{l}\text { (Robb et al., 2005, Takahashi et al., 2003, } \\
\text { Takahashi et al., 2008) }\end{array}$ \\
\hline LIFR & Leukemia inhibitory factor receptor & $\begin{array}{l}\text { Mutants die perinatally, TGC number reduced, spongiotrophoblast and } \\
\text { labyrinth layers disorganized }\end{array}$ & (Takahashi et al., 2003, Ware et al., 1995) \\
\hline Socs3 & Suppressor of cytokine signaling protein & $\begin{array}{l}\text { Mutants die by E13.5 with TGC number increased, spongiotrophoblast } \\
\text { and labyrinth layers reduced }\end{array}$ & $\begin{array}{l}\text { (Boyle and Robb, 2008, Robb et al., 2005, } \\
\text { Takahashi et al., 2003) }\end{array}$ \\
\hline Jak1 & Janus kinase 1 ; tyrosine kinase & $\begin{array}{l}\text { Mutants die perinatally, TGC number reduced and spongiotrophoblast } \\
\text { cell number increased, labyrinth layer disorganized }\end{array}$ & (Takahashi et al., 2008) \\
\hline Stat3 & $\begin{array}{l}\text { Signal transducer and activator of } \\
\text { transcription } 3\end{array}$ & Mutants die by E7.5 with TGC number decreased & (Takeda et al., 1997) \\
\hline$R X R$ & Retinoid X receptors & $\begin{array}{l}\mathrm{RXR} \alpha^{-1-} \text { die by E16.5 and } \mathrm{RXR} \alpha^{-1 /} / \mathrm{RXR} \beta^{-1 .} \text { compound homozygous die by } \\
\text { E10.5, TGCs disorganized, spongiotrophoblast reduced, labyrinth layer } \\
\text { absent }\end{array}$ & (Sapin et al., 1997, Wendling et al., 1999) \\
\hline PTHrP & Parathyroid hormone-related protein & $\begin{array}{l}\text { Promotes TGC differentiation in vitro } \\
\text { Mutants die immediately after birth }\end{array}$ & (El-Hashash et al., 2005, Karaplis et al., 1994) \\
\hline Fbw7 & $\begin{array}{l}\text { F-box protein component of an SCF (Skp1- } \\
\text { Cul1-F-box protein-Rbx1)-type ubiquitin } \\
\text { ligase }\end{array}$ & $\begin{array}{l}\text { Mutants die by E10.5, TGC number increased } \\
\text { TGCs, DNA synthesis increased }\end{array}$ & (Tetzlaff et al., 2004) \\
\hline $\mathrm{Chm}$ & Choroideremia (CHM); Rab escort protein-1 & $\begin{array}{l}\text { Mutants die by E11.5, TGC number increased, smaller ectoplacental } \\
\text { cone and reduced spongiotrophoblast layer }\end{array}$ & (Shi et al., 2004) \\
\hline CCNE1 and CCNE2 & Cyclin E1, E2 & $\begin{array}{l}\text { Cyclin } \mathrm{E}^{-1} \mathrm{E} 2^{-\%} \text { embryos die by E11.5, TGC nuclei have marked } \\
\text { reduction in DNA content though TGC nuclear size not reduced }\end{array}$ & (Geng et al., 2003, Parisi et al., 2003) \\
\hline$p 57^{\text {Kip2 }}$ & Cyclin-dependent kinase inhibitor & $\begin{array}{l}\text { Mutants die neonatally, spongiotrophoblast layer increased, TGC } \\
\text { number not different } \\
\text { Defines the length of the gap phase during endoreduplication }\end{array}$ & $\begin{array}{l}\text { (Hattori et al., 2000, Kanayama et al., 2002, } \\
\text { Takahashi et al., 2000) }\end{array}$ \\
\hline$p 53$ & $\begin{array}{l}\text { Tumour suppressor protein, transcriptional } \\
\text { factor }\end{array}$ & $\begin{array}{l}\text { Mutants die postnatally, TGC number increased, spongiotrophoblast } \\
\text { layer reduced }\end{array}$ & (Komatsu et al., 2007, Soloveva and Linzer, 2004) \\
\hline Mfn2 & Mitochondrial transmembrane GTPase & Mutants die by E11.5, TGC number reduced, smaller TGC nuclear size & (Chen et al., 2003) \\
\hline Geminin & Nuclear protein that inhibits DNA replication & $\begin{array}{l}\text { Mutants die at preimplantation stage, premature endoreduplication of } \\
\text { 'trophoblast-like' giant cells at eight cells stage }\end{array}$ & (Gonzalez et al., 2006) \\
\hline
\end{tabular}

endo-G2 phase with p57 ${ }^{\text {Kip2 }}$ accumulating upon completion of $S$ phase and an endo-G1 phase with $\mathrm{p} 57^{\mathrm{Kip} 2}$ declining several hours before entry into S-phase (Hattori et al., 2000). It is hypothesized that periodic expression of $\mathrm{p} 57^{\mathrm{Kip} 2}$ protein promotes alternating $\mathrm{S}$ and gap phases during the endocycle.

\section{Altered $G 1$ to $S$ checkpoint}

A G1 to $S$ checkpoint is present during the mitotic cell cycle to ensure that chromosomes are intact before replication. At the G1 checkpoint, the $\mathrm{Rb}$ tumor suppressor protein is phosphorylated by cyclin D/Cdk allowing the E2F transcription factor to be liberated, which in turn drives the cell cycle into $S$ phase (Sherr and Roberts, 2004). The p53 tumour suppressor protein helps cells to survey genotoxic damage and cooperates with $\mathrm{Rb}$ to regulate G1 arrest (Sherr, 2000). During the transition from the mitotic cell cycle to the endocycle in trophoblast cells, cyclin D isoform expression switches from D3 to D1 (MacAuley et al., 1998). Expression of p53 and Rb declines during TGC differentiation whereas their forced over-expression inhibits differentiation (Soloveva and Linzer, 2004). This altered G1 checkpoint control might allow cells to go through repeated $S$ phases without intervening mitoses.

\section{Maintenance of S phase cyclin/Cdk activities}

Cyclin E promotes the $\mathrm{G} 1$ to $S$ phase transition whereas cyclin A promotes S phase progression (Sherr and Roberts, 2004), and both cyclin A and E are expressed during endo-S phase (MacAuley et al., 1998). Cyclin E1/E2-deficient mice show a reduced endoreduplication in TGCs, indicating that cyclin $\mathrm{E}$ is essential for endoreduplication (Geng et al., 2003; Parisi et al., 2003). Conversely, cyclin E levels are elevated in Fbw7(Tetzlaff et al., 2004) and Cul1 (Wang et al., 1999) mutants due to compromised cyclin $\mathrm{E}$ degradation, and TGCs are larger than normal.

\section{Cell lineage origins of different TGC subtypes}

In addition to distinct localization and gene expression patterns, the different subtypes have different lineage origins and arise at different times during development (Fig. 2) (Simmons et al., 2007). Some of the P-TGCs arise directly from the $\sim 60$ mural trophectoderm cells in the blastocyst in a process called primary TGC differentiation. However, most of the several hundred PTGCs that are present by mid-gestation, and all of the other subtypes, arise from the polar trophectoderm through so-called secondary TGC differentiation. Historically, it has been hypothesized that secondary TGCs are derived from progenitor cells within the ectoplacental cone and the spongiotrophoblast layers that are Mash2 and Tpbpa/4311 positive (Simmons and Cross, 2005). However, lineage-tracing studies have shown that only some TGC subtypes arise from Tpbpa-positive precursor cells (Fig. 2) (Simmons et al., 2007). Both P-TGCs and C-TGCs have mixed developmental origins. In contrast, all of the SpA-TGCs originate from Tpbpa-positive cells, whereas all of the S-TGCs arise from Tpbpa-negative precursors (Fig. 2). While Tpbpa positive precursors are located in the outer ectoplacental cone 
starting at $\sim$ E8.5 and later in the spongiotrophoblast, the source of the Tpbpa-negative precursors is unknown but could be the extraembryonic ectoderm/chorion trophoblast cells, inner ectoplacental cone cells, or both. The chorion has distinct layers of cells by E8.5 that are thought to give rise to the three different trophoblast cell layers in the labyrinth including two multinucleated syncytiotrophoblast layers and S-TGCs (Fig. 1 and 2) (Simmons et al., 2008a).

\section{Regulators of TGC development}

A variety of factors regulate TGC development (Table 2). After implantation, the trophoblast lineage is maintained by proliferation of trophoblast stem cells that reside in the polar trophectoderm and that produce the bulk of the trophoblast lineage save for $\sim 60$ of the P-TGCs that derive from mural trophectoderm (Fig. 2). The trophoblast stem cell pool is maintained by FGF4/FGFR2 (Arman et al., 1998; Tanaka et al., 1998) and Nodal (GuzmanAyala et al., 2004) signaling and the AP2 $\gamma$ (Auman et al., 2002), Eomes (Russ et al., 2000), Err2 (Luo et al., 1997; Tremblay et al., 2001a), Foxd3 (Tompers et al., 2005) and Elf5 (Donnison et al., 2005) transcription factors. Mice that are deficient for these factors, in general, show premature TGC differentiation as a consequence of the failure to maintain trophoblast stem cells (Table 2).

\section{Genes involved in maintenance of the ectoplacental cone and/or spongiotrophoblast}

There are many genes involved in maintaining the ectoplacental cone and/or spongiotrophoblast (Table 2) and, in general, lossof-function mutations result in an increase in the number of TGCs. The precise mechanisms of action are established for only a few of these factors and only these will be discussed in detail. The basic helix-loop-helix (bHLH) transcription factor Mash2 plays an essential role in maintenance of the ectoplacental cone and spongiotrophoblast and negatively affects TGC differentiation (Guillemot et al., 1994; Scott et al., 2000; Tanaka et al., 1997). Mash2is expressed in the in the chorion, ectoplacental cone and later spongiotrophoblast (Scott et al., 2000). Mash2-deficient mice die by $\mathrm{E} 10$ due to placenta defects, which include the absence of spongiotrophoblast, an increase of TGCs and a failure of labyrinth formation (Guillemot et al., 1994; Tanaka et al., 1997). A similar phenotype is observed in mutants for the DNA methyltransferase 3-like gene Dnmt3L (Arima etal., 2006). Dnmt3L is required for the establishment of maternal methylation imprints, and Dnmt3L mat"/" mutants die by E10.5 due to an imprinting defect and expression of Mash2 is diminished (Arima et al., 2006).

Oxygen levels can regulate trophoblast lineage cell fate in mice both in vitroand in vivo(Adelman et al., 2000; Cowden Dahl et al., 2005). Hypoxia promotes in vitro differentiation of trophoblast stem cells into spongiotrophoblast cells as opposed to TGCs (Adelman et al., 2000; Takeda et al., 2006). Hypoxia inducible factors (HIFs) are heterodimeric basic helix-loop-helix/Per-ArntSim (bHLH/PAS) transcription factors composed of HIF $\beta /$ Arnt and HIF1 $\alpha$ or HIF2 $\alpha$, that are activated by hypoxia (Semenza, 2007). In HIF1 $\alpha / H I F 2 \alpha$ double mutants, there are fewer spongiotrophoblast and syncytiotrophoblast cells, and more TGCs (Cowden Dahl et al., 2005). Arntmutant placentas are similar to HIF1 $\alpha /$ HIF2 $\alpha$ mutants (Adelman et al., 2000; Cowden Dahl et al., 2005).
The $C \times 31$ and $C \times 31.1$ genes encode for connexin gap junction proteins and are involved in maintaining TGC progenitor cells within the ectoplacental cone and spongiotrophoblast (Kibschull et al., 2005; Kibschull et al., 2004; Plum et al., 2001; ZhengFischhofer et al., 2007). $C \times 31$ is expressed at pre-implantation stages, but is restricted to the ectoplacental cone and extraembryonic ectoderm after implantation and then it persists in spongiotrophoblast (Plum et al., 2001). Cx31.1 is co-expressed with $C \times 31$ at post-implantation stages, except that its expression is suppressed in spongiotrophoblast after E11.5 and persists in glycogen trophoblast cells (Zheng-Fischhofer et al., 2007). Cx31 and $C \times 31.1$ deficient mice show similar placental defects including excessive TGCs (Plum et al., 2001; Zheng-Fischhofer et al., 2007).

\section{Genes involved in TGC terminal differentiation}

A large number of factors are implicated in promoting the terminal differentiation of TGCs though most of the information to date is limited to insights into P-TGCs (Table 2). Only some of these factors will be discussed in detail in which the molecular and cellular function is understood.

Transcription factors. It is well established that bHLH factors play key roles in TGC differentiation. Hand1 plays an essential role in promoting TGC differentiation (Firulli et al., 1998; Riley et al., 1998; Scott et al., 2000). It is expressed in the upper layer of the chorion, ectoplacental cone and all TGC subtypes. In Hand1 mutants, the ectoplacental cone is smaller, the number of cells lining the implantation site is reduced and they are strikingly smaller than normal P-TGCs. Hand1 mutants die by E8.5 but, in studying Hand1-deficient trophoblast stem cells in culture, it appears that Hand1 is essential for differentiation of all four TGC subtypes (Simmons et al., 2007). Mash2, the bHLH protein that maintains the diploid TGC progenitors, antagonizes Hand1 action (Scott et al., 2000). Stra13, another bHLH factor that is induced by retinoic acid (Sapin et al., 2000), can induce TGC differentiation in vitro (Hughes et al., 2004). I-mfa, a bHLH factor interacting protein, promotes TGC differentiation by inhibiting Mash2 (Kraut et al., 1998).

Gata transcription factors are also implicated in TGC development. Gata2 and Gata3 regulate transcription of TGC-specific hormone genes (Ma et al., 1997; Ng et al., 1993; Ng et al., 1994). In addition, Gata2 has been implicated in restricting expression of the Plpa gene to P-TGCs that surround the ectoplacental cone (Ma and Linzer, 2000). The results are interesting because they may imply distinct regulatory mechanisms for TGCs that are derived from Tpbpa-positive versus Tpbpa-negative precursors.

Intercellular signaling pathways. Several signaling pathways are implicated in TGC development and highlight the importance of paracrine interactions. Leukemia inhibitory factor (LIF) is a member of the interleukin- 6 cytokine family and has several biological functions (Metcalf, 2003). LIF binds to a low-affinity receptor (LIFR), which in turn forms a high-affinity complex with the gp130 receptor protein. The LIFR-gp130 heterodimer complex transduces the LIF signal through activation of JAK kinase and STAT transcription factors (Metcalf, 2003). Suppressor of cytokine signaling (SOCS) proteins are important negative regulators of JAK-STAT signaling that form a negative-feedback loop-(Metcalf, 
2003). LIF is expressed in the uterus of pregnant mice (Shen and Leder, 1992) and promotes TGC differentiation both in cultured Rcho- 1 cells and in vivo (Takahashi et al., 2003; Takahashi et al., 2008). Deletion of Lifr results in placentas with fewer TGCs (Takahashi et al., 2003) and disorganized spongiotrophoblast and labyrinth layers (Ware et al., 1995), resulting in perinatal lethality. Jak1-deficient mice also die perinatally and show fewer TGCs with increased spongiotrophoblast cells, suggesting compromised differentiation from spongiotrophoblast to TGCs (Takahashi et al., 2008). In contrast, SOCS3 mutants have excessive TGCs and smaller spongiotrophoblast and labyrinth layers (Takahashi et al., 2008). Interestingly, reduction of Lif, Lifr or Jak1 gene dosage rescues the placental defects and embryonic lethality in SOCS3 mutant mice (Boyle and Robb, 2008; Robb et al., 2005; Takahashi et al., 2003; Takahashi etal., 2008).

Retinoic acid, the active derivative of vitamin A (retinol), promotes TGC differentiation in vivoand in vitro(Yan et al., 2001) and several retinoic acid-inducible genes, including Stra13, are expressed in the developing placenta (Sapin et al., 2000). When trophoblast stem cells are cultured with retinoic acid, their proliferation is compromised, TGC differentiation is induced but spongiotrophoblast reduced (Yan et al., 2001). Recent studies suggest that retinoic acid preferentially induces differentiation of P-TGCs and suppresses formation of the S-TGC and C-TGC subtypes, providing the first evidence that different TGC subtypes can be differentially regulated (Simmons et al., 2007). Retinoic acid receptors (RARs) and retinoid $X$ receptors (RXRs) form heterodimers that are the receptors for retinoic acid. $R X R \alpha$ mutants and $R X R \alpha / R X R \beta$ compound mutants die by $\mathrm{E} 16.5$ and E10.5, respectively, and show placenta defects that are mostly restricted to labyrinth (Sapin et al., 1997; Wendling et al., 1999). Single RAR mutants do not display obvious placental phenotypes suggesting redundancy among RARs in placental development and function.

Several growth factors affect TGC differentiation and/or the expression of TGC-specific genes including Activin (Erlebacher et al., 2004), EGF (Yamaguchi et al., 1995), TGF $\beta$ (Erlebacher et al., 2004; Yamaguchi et al., 1995), IGF-I (Kanai-Azuma et al., 1993), IGF-II (Kanai-Azuma etal., 1993), and PTHrP (El-Hashash etal., 2005; El-Hashash and Kimber, 2006). Many of these factors are expressed locally within the uterus or by trophoblast cells themselves. However, in most cases, whether these factors are critical for TGC differentiation in vivo has not been established through analysis of mouse mutants.

\section{Functions of TGCs}

TGCs have diverse functions that are crucial for implantation and subsequent placental function (Fig. 4). The mural trophectoderm-derived TGCs mediate attachment of blastocyst to the uterine epithelium, induce uterine decidulization, invade into the uterine stroma, and anastomose to form the yolk sac placenta for early exchange of nutrients and endocrine signals between mother and fetus. After implantation, TGCs produce hormones and cytokines for maintenance of the feto-maternal interface and regulation of maternal adaptations to pregnancy.

\section{Functions of TGCs in establishment of fetal-maternal inter- face}

Adhesion to the uterine epithelium

At the time of implantation, mural trophectoderm cells increase their adhesiveness and become competent to attach to the uterus (Armant, 2005). Meanwhile, uterine epithelial cells are primed by progesterone and estrogen from the ovary and become capable of attaching to the blastocyst (Dey et al., 2004). TGCs also produce progesterone (Yamamoto et al., 1994) that may contribute to regulation of uterine changes. During implantation, trophoblast cells attach to extracellular matrix (ECM) in the receptive uterus, which is composed of fibronectin, laminin, vitronectin and collagen (Sutherland, 2003; Wang and Armant, 2002). As the blastocytst and uterine epithelium attach, the now differentiating P-TGCs express several integrins such as $\alpha 5 \beta 1$ (Metcalf, 2003; Schultz and Armant, 1995), $\alpha 7 \beta 1$ (Klaffky et al., 2001), $\alpha 4 \beta 1$ (Basak et al., 2002), $\alpha$ llb $\beta 3$ (Rout et al., 2004) and $\alpha \mathrm{V} \beta 3$ (Rout et al., 2004).

\section{TGCs affect decidualization of the uterine stromal cells}

Upon attachment of the blastocyst to the uterine epithelium, the uterine stromal cells at sites of blastocyst apposition undergo proliferation and differentiation into decidual cells, a process called decidualization. The uterine stroma can undergo decidualization in response to even an artificial stimulus such as scratching of the epithelium or intraluminal injection of lectincoated beads or oil, as long as the uterus has been exposed to appropriate priming by estrogen and progesterone (Dey et al., 2004). TGCs are thought to be indispensible for decidualization because of their production either of progesterone or other signals that affect decidual cell differentiation (Bany and Cross, 2006). These latter signals are inferred from the fact that there are differences in gene expression between the decidua surrounding a normally implanted embryo compared to an artificially induced one, or surrounding mutant mouse embryos that have TGC
Paracrine Effects

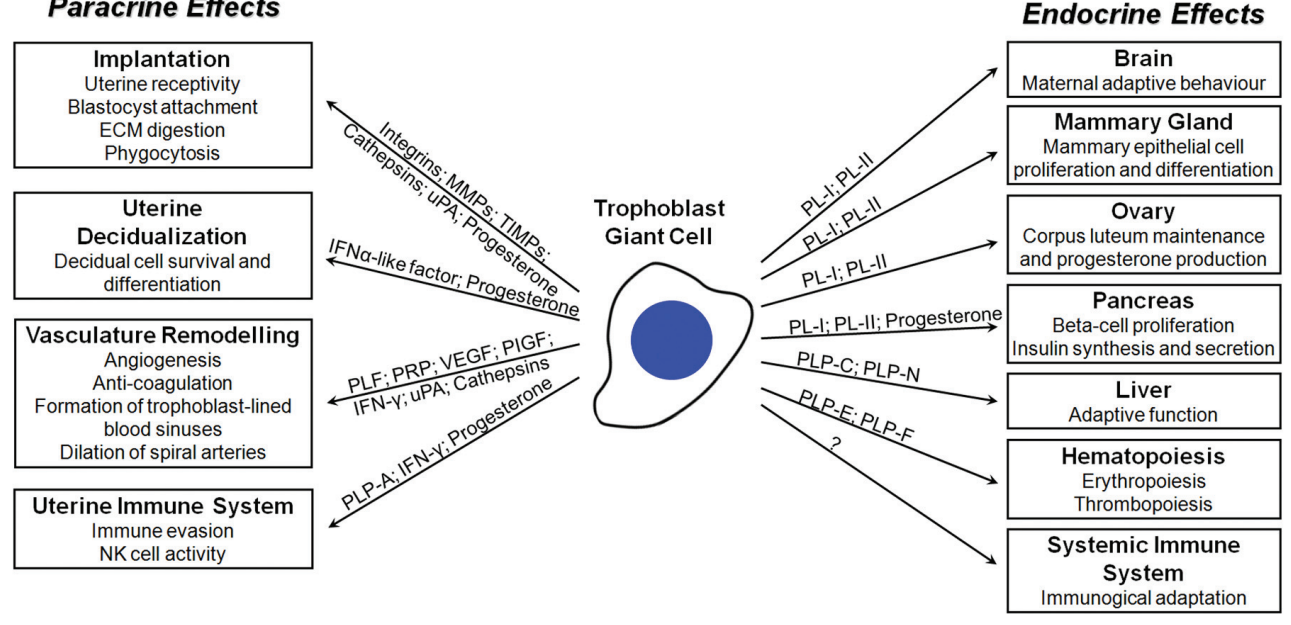

Fig. 4. Summary of the paracrine and endocrine functions of TGCs. 
defects (Bany and Cross, 2006). At least one of the TGC signals is a type I interferon (Bany and Cross, 2006).

\section{Invasion into the decidua and anastomosis with the maternal vasculature}

After attachment of the blastocyst to the uterine luminal epithelium, P-TGCs invade the uterus by remodeling of the ECM, phagocytosis and cell motility (Cross et al., 1994). They form a transient structure called the parietal yolk sac (Fig. 1) that is the site of exchange for nutrients and gases between the mother and fetus in the early post-implantation conceptus (Cross et al., 1994). It is composed of P-TGCs, parietal endoderm cells and an extensive basement membrane (Reichert's membrane) between them (Welsh and Enders, 1987). The formation of the yolk sac placenta is highly dependent on the ability of the TGCs to penetrate the uterine epithelium and anastomose with maternal blood spaces surrounding the implantation site. During anatomosis, the P-TGCs are highly protrusive, with long cytoplasmic lamina extended to envelope a diffuse network of maternal blood sinuses (Bevilacqua and Abrahamsohn, 1989; McRae and Church, 1990).

The mechanisms of trophoblast invasion are best studied in $\mathrm{P}$ TGCs but SpA-TGCs and glycogen trophoblast cells also invade into the uterus (Adamson et al., 2002; Pijnenborg et al., 1981). TGCs secrete a variety of proteinases that are thought to digest the ECM as well as phagocytosed maternal cells and matrix materials. They include matrix metalloproteinases (MMP-2, -3, 9, -13) and inhibitors of metalloproteinases (TIMP-1, -2, -3, -4) (Alexander et al., 1996; Das et al., 1997; Harvey et al., 1995; Teesalu et al., 1999; Zhang et al., 2003) urokinase plasminogen activators (Teesalu et al., 1998; Teesalu et al., 1999) and cathepsins (Afonso et al., 1999; Deussing et al., 2002; Hemberger et al., 2000; Ishida et al., 2004).

\section{Functions of TGCs after implantation}

After implantation, TGCs produce many paracrine and endocrine factors that target various maternal physiological systems to maintain maternal adaptations to pregnancy.

\section{Production of hormones that regulate various maternal physi- ological systems}

TGCs produce a broad range of hormones that regulate several maternal adaptations to pregnancy. In particular, the prolactin/placental lactogen (PL)/prolactin-like protein (PLP) gene family is highly evolved in rodents. There are 23 members in mice and all except for the pituitary prolactin gene are exclusively expressed in the placenta and in TGCs in particular (Simmons et al., 2008b, Wiemers et al., 2003). The expression patterns indicate that the 22 placenta-specific genes have diverse functions (Simmons et al., 2008b).

The PL were first identified in rodents as prolactin-related hormones that stimulate the mammary gland similar to prolactin and indeed they work through the prolactin receptor (Linzer and Fisher, 1999), though it is clear that PL has a variety of other target tissues. TGCs produce PL-I starting soon after implantation until mid-gestation and subsequently PL-II from mid-gestation until term (Talamantes, 1990). In mice in which the pituitary gland is removed as the source of prolactin, secretion of both PL-I (Lopez etal., 1991) and PL-II (Kishi etal., 1988) is elevated and some milk production occurs indicating that the placental lactogens are partially sufficient to promote mammary development (Thordarson et al., 1989). PL-I and PL-II also have luteotrophic effects on the ovary and support progesterone production (Galosy and Talamantes, 1995; Thordarson et al., 1997). PL-I and PL-II can also increase insulin secretion (Brelje et al., 1993; Fleenor et al., 2000; Nielsen et al., 1999; Sorenson and Brelje, 1997) and stimulate an increase in the number of insulin producing $\beta$ cells in pancreatic islets. By contrast, progesterone inhibits insulin secretion and $\beta$ cell division (Sorenson et al., 1993). PL-I affects the liver and induces expression of $\mathrm{Na}+$ /taurocholate-co-transporting polypeptide (NTCP) (Cao et al., 2001), which is critical for bile salt transport. Finally, prolactin modulates the response of the immune system to stress (Dorshkind and Horseman, 2001; Dugan et al., 2007; Dugan et al., 2002). It is not yet clear if PL-I and/or PLII have similar effects.

TGCs secrete several PLPs that regulate hematopoiesis. PLP$E$ and PLP-F can stimulate megakaryocytopoiesis and erythropoiesis (Bhattacharyya et al., 2002; Lefebvre et al., 2001; Lin and Linzer, 1999; Zhou et al., 2005). PLP-E is expressed at the first half of pregnancy by P-TGCs, whereas PLP-F is secreted later in pregnancy by the spongiotrophoblast layer (Simmons et al., $2008 b)$, suggesting that they function in a sequential manner. PLP-E has been shown to stimulate human and mouse erythroid progenitor cell proliferation and differentiation through activation of the JAK/STAT pathway (Bittorf et al., 2000). Proliferin 2 (PLF2) stimulates an increase in the fraction of long-term culture-initiating cells (LTC-IC) in cultured bone marrow cells (Choong et al., 2003).

\section{Production of paracrine factors that regulate the feto-maternal interface}

The vascular bed and repertoire of immune cells in the uterus changes dramatically during gestation. TGCs secrete the PLP cytokines proliferin (PLF) and proliferin-related protein (PRP) that stimulate and inhibit endothelial cell migration, respectively (Jackson et al., 1994). PLF is expressed in the early half of gestation and in all TGC subtypes except for S-TGCs (Simmons et al., 2007). PRP is subsequently expressed in the latter half of gestation and in all four subtypes of TGCs. TGCs also express vascular endothelial growth factor (VEGF) (Voss et al., 2000) and placental-like growth factor (PLGF) (Tayade et al., 2007) in early gestation. Antagonists of VEGF/PLGF are also expressed in the placenta. Flt-1 is a VEGF receptor that can undergo alternative splicing to result in a secreted Flt-1 protein (sFlt-1) that blocks VEGF action. sFLT-1 transcripts are detected in the spongiotrophoblast that lies beneath the P-TGCs (Cross et al., 2002; He et al., 1999), implying a mechanism by which maternal blood vessels are prevented from growing into the junctional zone.

TGCs also produce several factors that can regulate blood flow. First, they secrete PLP-A that in vitrocan inhibit the ability of NK cells to produce interferon- $\gamma$ (IFN $\gamma$ ) (Muller et al., 1999). Uterine NK cells are important for spiral artery dilatation through their production of interferon- $\gamma$ (Ashkar et al., 2000). TGCs also produce interferon- $\gamma$ during mid-gestation (Platt and Hunt, 1998), and could affect NK cell function directly. Despite the predictions from the expression patterns and in vitro activity of PLP-A, P/pa deficient mice have normal pregnancies unless the pregnant female mice are exposed to hypoxia (Ain et al., 2004). Second, 
TGCs express adrenomedullin (Montuenga etal., 1997; Yotsumoto et al., 1998), a vasodilator, and endothelial nitric oxide synthetase (eNos/Nos3) (Hemberger et al., 2003), an enzyme that produces the vasodilator nitric oxide (NO) and that is implicated in vasorelaxation during pregnancy (Gagioti et al., 2000). However, since spiral arteries at the feto-maternal interface lack smooth muscle, the targets of these vasodilators are unclear (Cross et al., 2002). Finally, trophoblast cells, like endothelial cells, suppress coagulation of blood whereas blood normally rapidly clots when hemorrhage occurs. P-TGCs, ectoplacental cone and spongiotrophoblast cells express thrombomodulin, a protein that has anti-coagulant effects on maternal blood within the parietal yolk sac and placenta (Isermann et al., 2003; Weiler-Guettler et al., 1996).

The activity of the local immune function is also altered during pregnancy in rodents to prevent the maternal immune system from killing the allogeneic conceptus. The precise mechanisms are unknown. Progesterone produced by TGCs may have some effect since it can stimulate activities of type $2 \mathrm{~T}$ helper cells (Th2) (Szekeres-Bartho and Wegmann, 1996) that can secrete cytokines (e.g., IL-10) that have feto-protective effects. There are significant changes in the distribution of NK cells during pregnancy associated with the presence of a normal conceptus (Herington and Bany, 2007). This implies that factors from the conceptus, likely from TGCs, regulate NK cell homing, proliferation and/or survival.

\section{Distinct or overlapping functions of the four different TGCs subtypes?}

Based on their distinct locations in the placenta and different gene expression patterns (Simmons et al., 2007; Simmons et al., 2008b), we speculate that the four subtypes of TGCs have distinct functions (Table 1). P-TGCs express the greatest variety of PLPs among all subtypes of TGCs (Simmons et al., 2008b). PL-I and $\mathrm{PL}-\mathrm{Il}$ can act on many maternal physiological systems such as corpus luteum, mammary gland, brain, and pancreas (Soares et al., 2007). The angiogenesis and hematopoiesis related hormones (PLF, PRP, PLP-A, PLP-E, PLP-F) are also expressed by P-TGCs (Simmons et al., 2008b), and may function early in establishing the parietal yolk sac before the circulation into the mature placenta is established. P-TGCs also express progesterone and interferon- $\gamma$ (Yamamoto et al., 1994; Platt and Hunt, 1998) which are important for decidualization and NK cell function. Thus, the functions of P-TGCs are very broad. In general, SpA-TGCs express factors that regulate cardiovascular functions including formation of blood vessels (PLF and PRP) and blood cells (PLF2, PLP-E, PLP-F), and dilation of spiral arteries (PLPA by affecting NK cells) (Simmons et al., 2008b). SpA-TGCs also express placenta-specific cathepsins, Cts 7 and Cts8, and Cts8 in particular is capable of mediating smooth muscle degradation and blood vessel disintegration to facilitate formation of trophoblast-lined blood sinuses (Screen et al., 2008). These would facilitate the maternal blood supply to the conceptus. The C-TGCs line the canals, but other than this structural role, it is difficult to imagine their function. S-TGCs produce the least number of PLP hormones (PL-II, PRP, PLP-K) (Simmons et al., 2008b). Their expression of PRP, but not PLF, suggests that growth of endothelial cells into the labyrinth may be inhibited which would be critical for maintaining the hemo-chorial blood space. S-TGCs also secrete cathepsin Q (Simmons et al., 2007), a cysteine protease with related family members implicated in trophoblast invasion, as described above, and hormone regulation. Some cathepsins can cleave prolactin into peptides that have alternative functions (Clapp et al., 2006; Hilfiker-Kleiner et al., 2007; Piwnica et al., 2006). The location of S-TGCs on the maternal side of the fetomaternal interface implies that they could cleave prolactin-like hormones before they leave the placenta and enter the maternal circulation.

\section{Summary}

Recent research has made striking progress in understanding the development and function of TGCs. There are at least four different subtypes of TGCs within the mature placenta, each arising at different times and locations in the placenta, and likely having distinct functions. While we now have a fairly good understanding of the regulation of TGC development, the functions of the different TGC subtypes remain very active areas of investigation and there are key open questions that should guide future studies. First, it will be intriguing to understand more details about the different functions of the TGC subtypes and how they are differentially regulated. Second, TGCs express a wide repertoire of hormones, but the biological function of most of these is unknown. Third, since it appears that TGCs regulate homeostatic physiological systems in the mother, it will be intriguing to see if and what type of physiological changes in the mother can alter the development and/or function of TGCs. There are insights from a variety of experimental animals that alteration of diet can affect placental development. Hypoxia during pregnancy can also alter expression of prolactin-like protein genes and supports the notion that these hormones may mediate responses to pregnancy stressors. These emerging themes will be important to pursue in order to gain better insights into the dialogue between the mother and fetus that occurs during pregnancy.

\section{Acknowledgements}

Work from the Cross lab was supported by grants from the Alberta Heritage Foundation for Medical Research (AHFMR) and the Canadian Institutes for Health Research. J.C.C. is an AHFMR Scientist.

\section{References}

ABBOTT, B.D. and BUCKALEW, A.R. (2000). Placental defects in ARNT-knockout conceptus correlate with localized decreases in VEGF-R2, Ang-1, and Tie-2. Dev Dyn 219: 526-538.

ADAMSON, S.L., LU, Y., WHITELEY, K.J., HOLMYARD, D., HEMBERGER, M., PFARRER, C. and CROSS, J.C. (2002). Interactions between trophoblast cells and the maternal and fetal circulation in the mouse placenta. Dev Bio/250: 358373.

ADELMAN, D.M., GERTSENSTEIN, M., NAGY, A., SIMON, M.C. and MALTEPE, E. (2000). Placental cell fates are regulated in vivo by HIF-mediated hypoxia responses. Genes Dev 14: 3191-3203.

AFONSO, S., ROMAGNANO, L. and BABIARZ, B. (1999). Expression of cathepsin proteinases by mouse trophoblast in vivo and in vitro. Dev Dyn 216: 374-384.

AIN, R., DAI, G., DUNMORE, J.H., GODWIN, A.R. and SOARES, M.J. (2004). A prolactin family paralog regulates reproductive adaptations to a physiological stressor. Proc Natl Acad Sci USA 101: 16543-16548.

ALEXANDER, C.M., HANSELL, E.J., BEHRENDTSEN, O., FLANNERY, M.L., KISHNANI, N.S., HAWKES, S.P. and WERB, Z. (1996). Expression and function of matrix metalloproteinases and their inhibitors at the maternalembryonic boundary during mouse embryo implantation. Development 122 : 
1723-1736

ARIMA, T., HATA, K., TANAKA, S., KUSUMI, M., LI, E., KATO, K., SHIOTA, K. SASAKI, H. and WAKE, N. (2006). Loss of the maternal imprint in Dnmt3Lmat/- mice leads to a differentiation defect in the extraembryonic tissue. Dev Bio/ 297: 361-373.

ARMAN, E., HAFFNER-KRAUSZ, R., CHEN, Y., HEATH, J.K. and LONAI, P. (1998). Targeted disruption of fibroblast growth factor (FGF) receptor 2 suggests a role for FGF signaling in pregastrulation mammalian development. Proc. Natl. Acad. Sci. USA 95: 5082-5087.

ARMANT, D.R. (2005). Blastocysts don't go it alone. Extrinsic signals fine-tune the intrinsic developmental program of trophoblast cells. Dev Bio/280: 260-280.

ARNOLD, S.J., MARETTO, S., ISLAM, A., BIKOFF, E.K. and ROBERTSON, E.J. (2006). Dose-dependent Smad1, Smad5 and Smad8 signaling in the early mouse embryo. Dev Bio/296: 104-118.

ASANOMA, K., KATO, H., YAMAGUCHI, S., SHIN, C.H., LIU, Z.P., KATO, K., INOUE, T., MIYANARI, Y., YOSHIKAWA, K., SONODA, K. et al. (2007). HOP NECC1, a novel regulator of mouse trophoblast differentiation. JBio/Chem282: 24065-24074.

ASHKAR, A.A., DI SANTO, J.P. and CROY, B.A. (2000). Interferon gamma contributes to initiation of uterine vascular modification, decidual integrity, and uterine natural killer cell maturation during normal murine pregnancy. JExpMed 192: 259-270.

AUMAN, H.J., NOTTOLI, T., LAKIZA, O., WINGER, Q., DONALDSON, S. and WILLIAMS, T. (2002). Transcription factor AP-2gamma is essential in the extraembryonic lineages for early postimplantation development. Development 129 : 2733-2747.

BANY, B.M. and CROSS, J.C. (2006). Post-implantation mouse conceptuses produce paracrine signals that regulate the uterine endometrium undergoing decidualization. Dev Bio/294: 445-456.

BASAK, S., DHAR, R. and DAS, C. (2002). Steroids modulate the expression of alpha4 integrin in mouse blastocysts and uterus during implantation. Bio/ Reprod 66: 1784-1789.

BEVILACQUA, E.M. and ABRAHAMSOHN, P.A. (1988). Ultrastructure of trophoblast giant cell transformation during the invasive stage of implantation of the mouse embryo. J. Morphol. 198: 341-351.

BEVILACQUA, E.M. and ABRAHAMSOHN, P.A. (1989). Trophoblast invasion during implantation of the mouse embryo. Arch Biol Med Exp (Santiago) 22: 107-118.

BHATTACHARYYA, S., LIN, J. and LINZER, D.I. (2002). Reactivation of a hematopoietic endocrine program of pregnancy contributes to recovery from thrombocytopenia. Mol Endocrino/16: 1386-1393.

BITTORF, T., JASTER, R., SOARES, M.J., SEILER, J., BROCK, J., FRIESE, K. and MULLER, H. (2000). Induction of erythroid proliferation and differentiation by a trophoblast-specific cytokine involves activation of the JAK/STAT pathway. $J$ Mol Endocrino/25: 253-262.

BOYLE, K. and ROBB, L. (2008). The role of SOCS3 in modulating leukaemia inhibitory factor signalling during murine placental development. $J$ Reprod Immunol77: 1-6.

BRELJE, T.C., SCHARP, D.W., LACY, P.E., OGREN, L., TALAMANTES, F., ROBERTSON, M., FRIESEN, H.G. and SORENSON, R.L. (1993). Effect of homologous placental lactogens, prolactins, and growth hormones on islet Bcell division and insulin secretion in rat, mouse, and human islets: implication for placental lactogen regulation of islet function during pregnancy. Endocrinology 132: 879-887.

BROSENS, I., DIXON, H.G. and ROBERTSON, W.B. (1977). Fetal growth retardation and the arteries of the placental bed. Br. J. Obstet. Gynaecol. 84: 656-663.

BROSENS, I.A., ROBERTSON, W.B. and DIXON, H.G. (1972). The role of the spiral arteries in the pathogenesis of preeclampsia. Obstet GynecolAnn1:177191.

CAO, J., GOWRI, P.M., GANGULY, T.C., WOOD, M., HYDE, J.F., TALAMANTES, F. and VORE, M. (2001). PRL, placental lactogen, and $\mathrm{GH}$ induce $N A(+) /$ taurocholate-cotransporting polypeptide gene expression by activating signal transducer and activator of transcription-5 in liver cells. Endocrinology 142: $4212-4222$

CARVALHO, A.F., KLISCH, K., MIGLINO, M.A., PEREIRA, F.T. and BEVILACQUA, E. (2006). Binucleate trophoblast giant cells in the water buffalo (Bubalus bubalis) placenta. J Morpho/267: 50-56.

CHEN, H., DETMER, S.A., EWALD, A.J., GRIFFIN, E.E., FRASER, S.E. and CHAN, D.C. (2003). Mitofusins Mfn1 and Mfn2 coordinately regulate mitochondrial fusion and are essential for embryonic development. J Ce// Bio/160: 189200.

CHOONG, M.L., TAN, A.C., LUO, B. and LODISH, H.F. (2003). A novel role for proliferin-2 in the ex vivo expansion of hematopoietic stem cells. FEBS Lett550: 155-162.

CLAPP, C., GONZALEZ, C., MACOTELA, Y., ARANDA, J., RIVERA, J.C., GARCIA, C., GUZMAN, J., ZAMORANO, M., VEGA, C., MARTIN, C. et al. (2006). Vasoinhibins: a family of $\mathrm{N}$-terminal prolactin fragments that inhibit angiogenesis and vascular function. Front Horm Res 35: 64-73.

COWDEN DAHL, K.D., FRYER, B.H., MACK, F.A., COMPERNOLLE, V., MALTEPE, E., ADELMAN, D.M., CARMELIET, P. and SIMON, M.C. (2005). Hypoxiainducible factors 1 alpha and 2alpha regulate trophoblast differentiation. Mol Cell Bio/25: 10479-10491.

CROSS, J.C., BACZYK, D., DOBRIC, N., HEMBERGER, M., HUGHES, M., SIMMONS, D.G., YAMAMOTO, H. and KINGDOM, J.C. (2003). Genes, development and evolution of the placenta. Placenta 24: 123-130.

CROSS, J.C., HEMBERGER, M., LU, Y., NOZAKI, T., WHITELEY, K., MASUTANI, M. and ADAMSON, S.L. (2002). Trophoblast functions, angiogenesis and remodeling of the maternal vasculature in the placenta. Mo/Ce//Endocrino/187: 207-212.

CROSS, J.C. and MICKELSON, L. (2006). Nutritional influences on implantation and placental development. Nutr Rev64: S12-8; discussion S72-S91.

CROSS, J.C., WERB, Z. and FISHER, S.J. (1994). Implantation and the placenta: key pieces of the development puzzle. Science 266: 1508-1518.

DAS, S.K., YANO, S., WANG, J., EDWARDS, D.R., NAGASE, H. and DEY, S.K. (1997). Expression of matrix metalloproteinases and tissue inhibitors of metalloproteinases in the mouse uterus during the peri-implantation period. Dev Genet 21: 44-54.

DEUSSING, J., KOUADIO, M., REHMAN, S., WERBER, I., SCHWINDE, A. and PETERS, C. (2002). Identification and characterization of a dense cluster of placenta-specific cysteine peptidase genes and related genes on mouse chromosome 13. Genomics 79: 225-240.

DEY, S.K., LIM, H., DAS, S.K., REESE, J., PARIA, B.C., DAIKOKU, T. and WANG, H. (2004). Molecular cues to implantation. Endocr Rev 25: 341-373.

DONNISON, M., BEATON, A., DAVEY, H.W., BROADHURST, R., L'HUILLIER, P. and PFEFFER, P.L. (2005). Loss of the extraembryonic ectoderm in Elf5 mutants leads to defects in embryonic patterning. Development 132: 22992308.

DORSHKIND, K. and HORSEMAN, N.D. (2001). Anterior pituitary hormones, stress, and immune system homeostasis. Bioessays 23: 288-294.

DUGAN, A.L., SCHWEMBERGER, S., NOEL, G.J., BABCOCK, G.F., OGLE, C.K., BUCKLEY, D.J., HORSEMAN, N.D. and GREGERSON, K.A. (2007). Stress and prolactin effects on bone marrow myeloid cells, serum chemokine and serum glucocorticoid levels in mice. Neuroimmunomodulation 14: 287-296.

DUGAN, A.L., THELLIN, O., BUCKLEY, D.J., BUCKLEY, A.R., OGLE, C.K. and HORSEMAN, N.D. (2002). Effects of prolactin deficiency on myelopoiesis and splenic T lymphocyte proliferation in thermally injured mice. Endocrinology 143 4147-4151.

EDGAR, B.A. and ORR-WEAVER, T.L. (2001). Endoreplication cell cycles: more for less. Cel/ 105: 297-306.

EL-HASHASH, A.H., ESBRIT, P. and KIMBER, S.J. (2005). PTHrP promotes murine secondary trophoblast giant cell differentiation through induction of endocycle, upregulation of giant-cell-promoting transcription factors and suppression of other trophoblast cell types. Differentiation 73: 154-174

EL-HASHASH, A.H. and KIMBER, S.J. (2006). PTHrP induces changes in cell cytoskeleton and E-cadherin and regulates Eph/Ephrin kinases and RhoGTPases in murine secondary trophoblast cells. Dev Bio/290: 13-31.

ELLEDGE, S.J. (1996). Cell cycle checkpoints: preventing an identity crisis. Science 274: 1664-72.

ERLEBACHER, A., PRICE, K.A. and GLIMCHER, L.H. (2004). Maintenance of mouse trophoblast stem cell proliferation by TGF-beta/activin. Dev Bio/275: 158-169.

FELDMAN, B., POUEYMIROU, W., PAPAIOANNOU, V.E., DECHAIRA, T.M. and 
GOLDFARB, M. (1995). Requirement of FGF-4 for postimplantation mouse development. Science 267: 246-249.

FIRULLI, A.B., MCFADDEN, D.G., LIN, Q., SRIVASTAVA, D. and OLSON, E.N. (1998). Heart and extra-embryonic mesodermal defects in mouse embryos lacking the bHLH transcription factor Hand1. Nat Genet 18: 266-270.

FLEENOR, D., PETRYK, A., DRISCOLL, P. and FREEMARK, M. (2000). Constitutive expression of placental lactogen in pancreatic beta cells: effects on cell morphology, growth, and gene expression. Pediatr Res 47: 136-142.

GAGIOTI, S., SCAVONE, C. and BEVILACQUA, E. (2000). Participation of the mouse implanting trophoblast in nitric oxide production during pregnancy. Bio/ Reprod 62: 260-268.

GALOSY, S.S. and TALAMANTES, F. (1995). Luteotropic actions of placental lactogens at midpregnancy in the mouse. Endocrinology 136: 3993-4003.

GENG, Y., YU, Q., SICINSKA, E., DAS, M., SCHNEIDER, J.E., BHATTACHARYA, S., RIDEOUT, W.M., BRONSON, R.T., GARDNER, H. and SICINSKI, P. (2003). Cyclin E ablation in the mouse. Cel/114: 431-443.

GONZALEZ, M.A., TACHIBANA, K.E., ADAMS, D.J., VAN DER WEYDEN, L., HEMBERGER, M., COLEMAN, N., BRADLEY, A. and LASKEY, R.A. (2006). Geminin is essential to prevent endoreduplication and to form pluripotent cells during mammalian development. Genes Dev 20: 1880-1884.

GU, Z., NOMURA, M., SIMPSON, B.B., LEI, H., FEIJEN, A., VAN DEN EIJNDENVAN RAAIJ, J., DONAHOE, P.K. and LI, E. (1998). The type I activin receptor ActRIB is required for egg cylinder organization and gastrulation in the mouse. Genes Dev 12: 844-857.

GUILLEMOT, F., NAGY, A., AUERBACH, A., ROSSANT, J. and JOYNER, A.L. (1994). Essential role of Mash-2 in extraembryonic development. Nature 371: 333-336.

GUZMAN-AYALA, M., BEN-HAIM, N., BECK, S. and CONSTAM, D.B. (2004). Nodal protein processing and fibroblast growth factor 4 synergize to maintain a trophoblast stem cell microenvironment. Proc Nat/ Acad Sci USA 101: 1565615660.

HARVEY, M.B., LECO, K.J., ARCELLANA-PANLILIO, M.Y.,ZHANG, X., EDWARDS, D.R. and SCHULTZ, G.A. (1995). Proteinase expression in early mouse embryos is regulated by leukaemia inhibitory factor and epidermal growth factor. Development 121: 1005-1014.

HATANO, N., MORI, Y., OH-HORA, M., KOSUGI, A., FUJIKAWA, T., NAKAI, N., NIWA, H., MIYAZAKI, J., HAMAOKA, T. and OGATA, M. (2003). Essential role for ERK2 mitogen-activated protein kinase in placental development. Genes Cells 8: 847-856.

HATTORI, N., DAVIES, T.C., ANSON-CARTWRIGHT, L. and CROSS, J.C. (2000). Periodic expression of the Cdk inhibitor p57Kip2 in trophoblast giant cells defines a G2-like gap phase of the endocycle. Mol. Biol. Cel/11: 1037-1045.

HE, Y., SMITH, S.K., DAY, K.A., CLARK, D.E., LICENCE, D.R. and CHARNOCKJONES, D.S. (1999). Alternative splicing of vascular endothelial growth factor (VEGF)-R1 (FLT-1) pre-mRNA is important for the regulation of VEGF activity. Mol Endocrinol 13: 537-545.

HEMBERGER, M. (2008). IFPA award in placentology lecture - characteristics and significance of trophoblast giant cells. Placenta 29 Suppl A: S4-S9.

HEMBERGER, M., HIMMELBAUER, H., RUSCHMANN, J., ZEITZ, C. and FUNDELE, R. (2000). cDNA subtraction cloning reveals novel genes whose temporal and spatial expression indicates association with trophoblast invasion. Dev Bio/222: 158-169.

HEMBERGER, M., NOZAKI, T., MASUTANI, M. and CROSS, J.C. (2003). Differential expression of angiogenic and vasodilatory factors by invasive trophoblast giant cells depending on depth of invasion. Dev Dyn 227: 185-191.

HERINGTON, J.L. and BANY, B.M. (2007). Effect of the conceptus on uterine natural killer cell numbers and function in the mouse uterus during decidualization. Biol Reprod 76: 579-588.

HERNANDEZ-VERDUN, D. and LEGRAND, C. (1975). In vitro study of chorionic and ectoplacental trophoblast differentiation in the mouse. J Embryol Exp Morpho/34: 633-644.

HESSE, M., FRANZ, T., TAMAI, Y., TAKETO, M.M. and MAGIN, T.M. (2000). Targeted deletion of keratins 18 and 19 leads to trophoblast fragility and early embryonic lethality. EMBO J19: 5060-5070

HILFIKER-KLEINER, D., KAMINSKI, K., PODEWSKI, E., BONDA, T., SCHAEFER, A., SLIWA, K., FORSTER, O., QUINT, A., LANDMESSER, U., DOERRIES, C. et al. (2007). A cathepsin D-cleaved $16 \mathrm{kDa}$ form of prolactin mediates postpartum cardiomyopathy. Ce//128: 589-600.

HITZ, C., VOGT-WEISENHORN, D., RUIZ, P., WURST, W. and FLOSS, T. (2005). Progressive loss of the spongiotrophoblast layer of Birc6/Bruce mutants results in embryonic lethality. Genesis 42: 91-103.

HO-CHEN, J.K., BUSTAMANTE, J.J. and SOARES, M.J. (2007). Prolactin-like protein-f subfamily of placental hormones/cytokines: responsiveness to maternal hypoxia. Endocrinology 148: 559-65.

HUGHES, M., DOBRIC, N., SCOTT, I.C., SU, L., STAROVIC, M., ST-PIERRE, B. EGAN, S.E., KINGDOM, J.C. and CROSS, J.C. (2004). The Hand1, Stra13 and Gcm 1 transcription factors override FGF signaling to promote terminal differentiation of trophoblast stem cells. Dev Bio/271: 26-37.

ISERMANN, B., SOOD, R., PAWLINSKI, R., ZOGG, M., KALLOWAY, S., DEGEN, J.L., MACKMAN, N. and WEILER, H. (2003). The thrombomodulin-protein C system is essential for the maintenance of pregnancy. Nat Med9: 331-337.

ISHIDA, M., ONO, K., TAGUCHI, S., OHASHI, S., NAITO, J., HORIGUCHI, K. and HARIGAYA, T. (2004). Cathepsin gene expression in mouse placenta during the latter half of pregnancy. J Reprod Dev50: 515-523.

JACKSON, D., VOLPERT, O.V., BOUCK, N. and LINZER, D.I. (1994). Stimulation and inhibition of angiogenesis by placental proliferin and proliferin-related protein. Science 266: 1581-1584

JAQUEMAR, D., KUPRIYANOV, S., WANKELL, M., AVIS, J., BENIRSCHKE, K. BARIBAULT, H. and OSHIMA, R.G. (2003). Keratin 8 protection of placental barrier function. J Cell Bio/161: 749-756.

KANAI-AZUMA, M., KANAI, Y., KUROHMARU, M., SAKAI, S. and HAYASHI, Y. (1993). Insulin-like growth factor (IGF)-I stimulates proliferation and migration of mouse ectoplacental cone cells, while IGF-II transforms them into trophoblastic giant cells in vitro. Biol. Reprod. 48: 252-261.

KANAYAMA, N., TAKAHASHI, K., MATSUURA, T., SUGIMURA, M., KOBAYASHI, T., MONIWA, N., TOMITA, M. and NAKAYAMA, K. (2002). Deficiency in p57Kip2 expression induces preeclampsia-like symptoms in mice. Mol Hum Reprod8: 1129-1135.

KARAPLIS, A.C., LUZ, A., GLOWACKI, J., BRONSON, R.T., TYBULEWICZ, V.L., KRONENBERG, H.M. and MULLIGAN, R.C. (1994). Lethal skeletal dysplasia from targeted disruption of the parathyroid hormone-related peptide gene. Genes Dev 8, 277-289.

KIBSCHULL, M., MAGIN, T.M., TRAUB, O. and WINTERHAGER, E. (2005). C×31 and $\mathrm{C} \times 43$ double-deficient mice reveal independent functions in murine placental and skin development. Dev Dyn 233: 853-863.

KIBSCHULL, M., NASSIRY, M., DUNK, C., GELLHAUS, A., QUINN, J.A., ROSSANT, J., LYE, S.J. and WINTERHAGER, E. (2004). Connexin31-deficient trophoblast stem cells: a model to analyze the role of gap junction communication in mouse placental development. Dev Bio/273: 63-75.

KISHI, K., OGREN, L., SOUTHARD, J.N. and TALAMANTES, F. (1988). Pituitary factors regulating mouse placental lactogen-II secretion during the last half of pregnancy in mice. Endocrinology 122: 2309-2317.

KLAFFKY, E., WILLIAMS, R., YAO, C.C., ZIOBER, B., KRAMER, R. and SUTHERLAND, A. (2001). Trophoblast-specific expression and function of the integrin alpha 7 subunit in the peri-implantation mouse embryo. Dev Bio/239: $161-175$

KLISCH, K., BEVILACQUA, E. and OLIVERA, L.V. (2005). Mitotic polyploidization in trophoblast giant cells of the alpaca. Cells Tissues Organs 181: 103-108.

KLISCH, K., HECHT, W., PFARRER, C., SCHULER, G., HOFFMANN, B. and LEISER, R. (1999). DNA content and ploidy level of bovine placentomal trophoblast giant cells. Placenta 20: 451-458.

KLISCH, K., THOMSEN, P.D., DANTZER, V. and LEISER, R. (2004). Genome multiplication is a generalised phenomenon in placentomal and interplacentomal trophoblast giant cells in cattle. Reprod Fertil Dev 16: 301-306.

KOHN, M.J., BRONSON, R.T., HARLOW, E., DYSON, N.J. and YAMASAKI, L. (2003). Dp1 is required for extra-embryonic development. Development 130 1295-1305.

KOMATSU, D., ABE, T., SANO, Y., SHIMAZAKI, K., TOMITA, M., KANAYAMA, N and TAKAHASHI, K. (2007). Increase of the trophoblast giant cells with prolactin-releasing peptide (PrRP) receptor expression in p53-null mice. Mol Reprod Dev 74, 1089-1094.

KRAUT, N., SNIDER, L., CHEN, C., TAPSCOTT, S.J. and GROUDINE, M. (1998). 
Requirement of the mouse I-mfa gene for placental development and skeletal patterning. EMBO J. 17: 6276-6288.

KRUGER, I., VOLLMER, M., SIMMONS, D.G., ELSASSER, H.P., PHILIPSEN, S. and SUSKE, G. (2007). Sp1/Sp3 compound heterozygous mice are not viable: impaired erythropoiesis and severe placental defects. Dev Dyn 236: 22352244.

LARKINS, B.A., DILKES, B.P., DANTE, R.A., COELHO, C.M., WOO, Y. and LIU, Y. (2001). Investigating the hows and whys of DNA endoreduplication. JExp Bot 52: $183-192$

LECHLEIDER, R.J., RYAN, J.L., GARRETT, L., ENG, C., DENG, C., WYNSHAWBORIS, A. and ROBERTS, A.B. (2001). Targeted mutagenesis of Smad1 reveals an essential role in chorioallantoic fusion. Dev Bio/240: 157-167.

LEFEBVRE, P., LIN, J., LINZER, D.I. and COHEN, I. (2001). Murine prolactin-like protein $E$ synergizes with human thrombopoietin to stimulate expansion of human megakaryocytes and their precursors. Exp Hemato/29: 51-58.

LIN, J. and LINZER, D.I. (1999). Induction of megakaryocyte differentiation by a novel pregnancy-specific hormone. J Biol Chem 274: 21485-21489.

LINZER, D.I. and FISHER, S.J. (1999). The placenta and the prolactin family of hormones: regulation of the physiology of pregnancy. Mol Endocrino/13: 837840.

LOPEZ, M.F., CARRION, F.A. and TALAMANTES, F. (1991). Pituitary-placental interaction: hypophysectomy modulates the secretion of mouse placental lactogen-I. Endocrinology 129: 2325-2328.

LOTZ, K., PYROWOLAKIS, G. and JENTSCH, S. (2004). BRUCE, a giant E2/E3 ubiquitin ligase and inhibitor of apoptosis protein of the trans-Golgi network, is required for normal placenta development and mouse survival. Mo/ Cel/ Bio/24: 9339-9350.

LUO, J., SLADEK, R., BADER, J.-A., MATTHYSSEN, A., ROSSANT, J. and GIGUERE, V. (1997). Placental abnormalities in mouse embryos lacking the orphan nuclear receptor ERR-b. Nature 388: 778-782.

MA, G.T. and LINZER, D.I. (2000). GATA-2 restricts prolactin-like protein A expression to secondary trophoblast giant cells in the mouse. Biol Reprod 63: 570-574.

MA, G.T., ROTH, M.E., GROSKOPF, J.C., TSAI, F.Y., ORKIN, S.H., GROSVELD, F., ENGEL, J.D. and LINZER, D.I. (1997). GATA-2 and GATA-3 regulate trophoblast-specific gene expression in vivo. Development 124: 907-914.

MA, G.T., SOlOVEVA, V., TZENG, S.J., LOWE, L.A., PFENDLER, K.C., IANNACCONE, P.M., KUEHN, M.R. and LINZER, D.I. (2001). Nodal regulates trophoblast differentiation and placental development. Dev Bio/236: 124-135.

MACAULEY, A., CROSS, J.C. and WERB, Z. (1998). Reprogramming the cell cycle for endoreduplication in rodent trophoblast cells. Mol. Biol. Cel/9: 795-807.

MCGARRY, T.J. and KIRSCHNER, M.W. (1998). Geminin, an inhibitor of DNA replication, is degraded during mitosis. Cel/93: 1043-1053.

MCRAE, A.C. and CHURCH, R.B. (1990). Cytoplasmic projections of trophectoderm distinguish implanting from preimplanting and implantation-delayed mouse blastocytes. J Reprod Fertil 88: 31-40.

METCALF, D. (2003). The unsolved enigmas of leukemia inhibitory factor. Stem Cells 21: 5-14.

MONKLEY, S.J., ZHOU, X.H., KINSTON, S.J., GIBLETT, S.M., HEMMINGS, L., PRIDDLE, H., BROWN, J.E., PRITCHARD, C.A., CRITCHLEY, D.R. and FASSLER, R. (2000). Disruption of the talin gene arrests mouse development at the gastrulation stage. Dev Dyn 219: 560-574.

MONTUENGA, L.M., MARTINEZ, A., MILLER, M.J., UNSWORTH, E.J. and CUTTITTA, F. (1997). Expression of adrenomedullin and its receptor during embryogenesis suggests autocrine or paracrine modes of action. Endocrinology 138: 440-451.

MULLER, H., LIU, B., CROY, B.A., HEAD, J.R., HUNT, J.S., DAI, G. and SOARES, M.J. (1999). Uterine natural killer cells are targets for a trophoblast cell- specific cytokine, prolactin-like protein A. Endocrinology 140: 2711-2720.

MURAKAMI, M., ICHISAKA, T., MAEDA, M., OSHIRO, N., HARA, K., EDENHOFER, F., KIYAMA, H., YONEZAWA, K. and YAMANAKA, S. (2004). mTOR is essential for growth and proliferation in early mouse embryos and embryonic stem cells. Mol Cel/ Bio/24: 6710-6718.

NADRA, K., ANGHEL, S.I., JOYE, E., TAN, N.S., BASU-MODAK, S., TRONO, D., WAHLI, W. and DESVERGNE, B. (2006). Differentiation of trophoblast giant cells and their metabolic functions are dependent on peroxisome proliferatoractivated receptor beta/delta. Mol Cell Bio/26: 3266-3281.

NAKAYAMA, H., SCOTT, I.C. and CROSS, J.C. (1998). The transition to endoreduplication in trophoblast giant cells is regulated by the mSNA zincfinger transcription factor. Dev. Biol. 199: 150-163.

NG, Y.K., ENGEL, J.D. and LINZER, D.I.H. (1993). Involvement of the GATA-3 transcription factor in trophoblast-specific expression of the mouse placental lactogen-I gene. Mol. Biol. Cel/4 (Supplement): 195a.

NG, Y.K., GEORGE, K.M., ENGEL, J.D. and LINZER, D.I. (1994). GATA factor activity is required for the trophoblast-specific transcriptional regulation of the mouse placental lactogen I gene. Development 120: 3257-3266.

NIELSEN, J.H., SVENSSON, C., GALSGAARD, E.D., MOLDRUP, A. and BILLESTRUP, N. (1999). Beta cell proliferation and growth factors. J Mol Med 77: 62-66.

PALAZON, L.S., DAVIES, T.J. and GARDNER, R.L. (1998). Translational inhibition of cyclin B1 and appearance of cyclin D1 very early in the differentiation of mouse trophoblast giant cells. Mol Hum Reprod 4: 1013-1020.

PAPADAKI, C., ALEXIOU, M., CECENA, G., VERYKOKAKIS, M., BILITOU, A., CROSS, J.C., OSHIMA, R.G. and MAVROTHALASSITIS, G. (2007). Transcriptional repressor erf determines extraembryonic ectoderm differentiation. Mol Cell Bio/27: 5201-5213.

PARISI, T., BECK, A.R., ROUGIER, N., MCNEIL, T., LUCIAN, L., WERB, Z. and AMATI, B. (2003). Cyclins E1 and E2 are required for endoreplication in placental trophoblast giant cells. EMBO J22: 4794-4803.

PIJNENBORG, R., DIXON, G., ROBERTSON, W.B. and BROSENS, I. (1980). Trophoblastic invasion of human decidua from 8 to 18 weeks of pregnancy. Placenta 1: 3-19.

PIJNENBORG, R., ROBERTSON, W.B., BROSENS, I. and DIXON, G. (1981). Review article: trophoblast invasion and the establishment of haemochorial placentation in man and laboratory animals. Placenta 2: 71-91.

PIWNICA, D., FERNANDEZ, I., BINART, N., TOURAINE, P., KELLY, P.A. and GOFFIN, V. (2006). A new mechanism for prolactin processing into $16 \mathrm{~K} P \mathrm{PL}$ by secreted cathepsin D. Mol Endocrino/20: 3263-3278.

PLATT, J.S. and HUNT, J.S. (1998). Interferon-gamma gene expression in cycling and pregnant mouse uterus: temporal aspects and cellular localization. $J$ Leukoc Bio/64: 393-400.

PLUM, A., WINTERHAGER, E., PESCH, J., LAUTERMANN, J., HALLAS, G., ROSENTRETER, B., TRAUB, O., HERBERHOLD, C. and WILLECKE, $\mathrm{K}$ (2001). Connexin31-deficiency in mice causes transient placental dysmorphogenesis but does not impair hearing and skin differentiation. Dev Biol 231: 334-347.

RAWN, S.M. and CROSS, J.C. (2008). The evolution, regulation, and function of placenta-specific genes. Annu Rev Cell Dev Biol 24: 158-181.

RILEY, P., ANSON-CARTWRIGHT, L. and CROSS, J.C. (1998). The Hand1 bHLH transcription factor is essential for placentation and cardiac morphogenesis. Nat. Genet. 18: 271-275.

ROBB, L., BOYLE, K., RAKAR, S., HARTLEY, L., LOCHLAND, J., ROBERTS, A.W., ALEXANDER, W.S. and METCALF, D. (2005). Genetic reduction of embryonic leukemia-inhibitory factor production rescues placentation in SOCS3null embryos but does not prevent inflammatory disease. Proc Natl Acad Sci USA 102: 16333-16338.

RODRIGUEZ, T.A., SPARROW, D.B., SCOTT, A.N., WITHINGTON, S.L., PREIS, J.I., MICHALICEK, J., CLEMENTS, M., TSANG, T.E., SHIODA, T., BEDDINGTON, R.S. et al. (2004). Cited1 is required in trophoblasts for placental development and for embryo growth and survival. Mol Cell Biol24: 228-244

ROUT, U.K., WANG, J., PARIA, B.C. and ARMANT, D.R. (2004). Alpha5beta1, alphaVbeta3 and the platelet-associated integrin alphallbbeta3 coordinately regulate adhesion and migration of differentiating mouse trophoblast cells. Dev Bio/268: 135-151.

RUSS, A.P., WATTLER, S., COLLEDGE, W.H., APARICIO, S.A., CARLTON, M.B. PEARCE, J.J., BARTON, S.C., SURANI, M.A., RYAN, K., NEHLS, M.C. et al. (2000). Eomesodermin is required for mouse trophoblast development and mesoderm formation. Nature 404: 95-99.

SABA-EL-LEIL, M.K., VELLA, F.D., VERNAY, B., VOISIN, L., CHEN, L., LABRECQUE, N., ANG, S.L. and MELOCHE, S. (2003). An essential function 
of the mitogen-activated protein kinase Erk2 in mouse trophoblast development. EMBO Rep 4: 964-968.

SAPIN, V., BOUILLET, P., OULAD-ABDELGHANI, M., DASTUGUE, B., CHAMBON, P. and DOLLE, P. (2000). Differential expression of retinoic acid-inducible (Stra) genes during mouse placentation. Mech. Dev. 92: 295-299.

SAPIN, V., DOLLE, P., HINDELANG, C., KASTNER, P. and CHAMBON, P. (1997). Defects of the chorioallantoic placenta in mouse RXRalpha null fetuses. Dev Biol191: 29-41.

SCHULTZ, J.F. and ARMANT, D.R. (1995). Beta 1- and beta 3-class integrins mediate fibronectin binding activity at the surface of developing mouse periimplantation blastocysts. Regulation by ligand-induced mobilization of stored receptor. J Biol Chem 270: 11522-11531.

SCOTT, I.C., ANSON-CARTWRIGHT, L., RILEY, P., REDA, D. and CROSS, J.C. (2000). The Hand1 basic helix-loop-helix transcription factor regulates trophoblast giant cell differentitation via multiple mechanisms. Mol. Cell. Biol. 20: 530541.

SCREEN, M., DEAN, W., CROSS, J.C. and HEMBERGER, M. (2008). Cathepsin proteases have distinct roles in trophoblast function and vascular remodelling. Development 135, 3311-3320.

SEMENZA, G.L. (2007). Hypoxia-inducible factor 1 (HIF-1) pathway. Sci STKE 2007: $\mathrm{cm} 8$.

SHEN, M.M. and LEDER, P. (1992). Leukemia inhibitory factor is expressed by the preimplantation uterus and selectively blocks primitive ectoderm formation in vitro. Proc. Natl. Acad. Sci. USA 89: 8240-8244.

SHERR, C.J. (2000). The Pezcoller lecture: cancer cell cycles revisited. Cancer Res 60: 3689-3695.

SHERR, C.J. and ROBERTS, J.M. (2004). Living with or without cyclins and cyclindependent kinases. Genes Dev18: 2699-2711.

SHI, W., VAN DEN HURK, J.A., ALAMO-BETHENCOURT, V., MAYER, W., WINKENS, H.J., ROPERS, H.H., CREMERS, F.P. and FUNDELE, R. (2004). Choroideremia gene product affects trophoblast development and vascularization in mouse extra-embryonic tissues. Dev Bio/272: 53-65.

SIMMONS, D.G. and CROSS, J.C. (2005). Determinants of trophoblast lineage and cell subtype specification in the mouse placenta. Dev Bio/284: 12-24.

SIMMONS, D.G., FORTIER, A.L. and CROSS, J.C. (2007). Diverse subtypes and developmental origins of trophoblast giant cells in the mouse placenta. Dev Biol 304: 567-578.

SIMMONS, D.G., NATALE, D.R., BEGAY, V., HUGHES, M., LEUTZ, A. and CROSS, J.C. (2008a). Early patterning of the chorion leads to the trilaminar trophoblast cell structure in the placental labyrinth. Development 135: 20832091.

SIMMONS, D.G., RAWN, S.M., DAVIES, A., HUGHES, M. and CROSS, J.C. (2008b). Spatial and temporal expression of the 23 murine Prolactin/Placental Lactogen-related genes is not associated with their position in the locus. BMC Genomics 9: 352

SOARES, M.J., KONNO, T. and ALAM, S.M. (2007). The prolactin family: effectors of pregnancy-dependent adaptations. Trends Endocrinol Metab 18: 114-121.

SOLOVEVA, V. and LINZER, D.I. (2004). Differentiation of placental trophoblast giant cells requires downregulation of $\mathrm{p} 53$ and $\mathrm{Rb}$. Placenta 25: 29-36.

SONG, J., OH, S.P., SCHREWE, H., NOMURA, M., LEI, H., OKANO, M., GRIDLEY, T. and LI, E. (1999). The type II activin receptors are essential for egg cylinder growth, gastrulation, and rostral head development in mice. Dev Bio/213: 157169.

SORENSON, R.L. and BRELJE, T.C. (1997). Adaptation of islets of Langerhans to pregnancy: beta-cell growth, enhanced insulin secretion and the role of lactogenic hormones. Horm Metab Res 29: 301-307.

SORENSON, R.L., BRELJE, T.C. and ROTH, C. (1993). Effects of steroid and lactogenic hormones on islets of Langerhans: a new hypothesis for the role of pregnancy steroids in the adaptation of islets to pregnancy. Endocrinology133: 2227-2234.

SUTHERLAND, A. (2003). Mechanisms of implantation in the mouse: differentiation and functional importance of trophoblast giant cell behavior. Dev Bio/258: 241-251.

SZEKERES-BARTHO, J. and WEGMANN, T.G. (1996). A progesterone-dependent immunomodulatory protein alters the Th1/Th2 balance. JReprod /mmunol 31: 81-95.
TAKAHASHI, K., KOBAYASHI, T. and KANAYAMA, N. (2000). p57(Kip2) regulates the proper development of labyrinthine and spongiotrophoblasts. Mol Hum Reprod 6: 1019-1025.

TAKAHASHI, Y., CARPINO, N., CROSS, J.C., TORRES, M., PARGANAS, E. and IHLE, J.N. (2003). SOCS3: an essential regulator of LIF receptor signaling in trophoblast giant cell differentiation. EMBO J22: 372-384.

TAKAHASHI, Y., TAKAHASHI, M., CARPINO, N., JOU, S.T., CHAO, J.R., TANAKA S., SHIGEYOSHI, Y., PARGANAS, E. and IHLE, J.N. (2008). Leukemia inhibitory factor regulates trophoblast giant cell differentiation via Janus kinase 1 signal transducer and activator of transcription 3-suppressor of cytokine signaling 3 pathway. Mol Endocrino/22: 1673-1681.

TAKEDA, K., NOGUCHI, K., SHI, W., TANAKA, T., MATSUMOTO, M., YOSHIDA N., KISHIMOTO, T. and AKIRA, S. (1997). Targeted disruption of the mouse Stat3 gene leads to early embryonic lethality. Proc Natl Acad Sci U S A 94, 3801 3804.

TAKEDA, K., HO, V.C., TAKEDA, H., DUAN, L.J., NAGY, A. and FONG, G.H. (2006). Placental but not heart defects are associated with elevated hypoxiainducible factor alpha levels in mice lacking prolyl hydroxylase domain protein 2. Mol Cel/ Bio/26: 8336-8346.

TALAMANTES, F. (1990). Structure and regulation of secretion of mouse placental lactogens. Prog Clin Biol Res 342: 81-85.

TAMAI, Y., ISHIKAWA, T., BOSL, M.R., MORI, M., NOZAKI, M., BARIBAULT, H., OSHIMA, R.G. and TAKETO, M.M. (2000). Cytokeratins 8 and 19 in the mouse placental development. J Cel/ Bio/151: 563-572.

TANAKA, M., GERTSENSTEIN, M., ROSSANT, J. and NAGY, A. (1997). Mash2 acts cell autonomously in mouse spongiotrophoblast development. Dev. Biol. 190: 55-65.

TANAKA, S., KUNATH, T., HADJANTONAKIS, A.K., NAGY, A. and ROSSANT, J. (1998). Promotion of trophoblast stem cell proliferation by FGF4. Science 282: 2072-2075.

TAYADE, C., HILCHIE, D., HE, H., FANG, Y., MOONS, L., CARMELIET, P., FOSTER, R.A. and CROY, B.A. (2007). Genetic deletion of placenta growth factor in mice alters uterine NK cells. J Immuno/178: 4267-4275.

TEESALU, T., BLASI, F. and TALARICO, D. (1998). Expression and function of the urokinase type plasminogen activator during mouse hemochorial placental development. Dev Dyn 213: 27-38.

TEESALU, T., MASSON, R., BASSET, P., BLASI, F. and TALARICO, D. (1999). Expression of matrix metalloproteinases during murine chorioallantoic placenta maturation. Dev Dyn 214: 248-258.

TETZLAFF, M.T., YU, W., LI, M., ZHANG, P., FINEGOLD, M., MAHON, K., HARPER, J.W., SCHWARTZ, R.J. and ELLEDGE, S.J. (2004). Defective cardiovascular development and elevated cyclin $E$ and Notch proteins in mice lacking the Fbw7 F-box protein. Proc Natl Acad Sci USA 101: 3338-3345.

THORDARSON, G., GALOSY, S., GUDMUNDSSON, G.O., NEWCOMER, B., SRIDARAN, R. and TALAMANTES, F. (1997). Interaction of mouse placental lactogens and androgens in regulating progesterone release in cultured mouse luteal cells. Endocrinology 138: 3236-3241.

THORDARSON, G., OGREN, L., DAY, J.R., BOWENS, K., FIELDER, P. and TALAMANTES, F. (1989). Mammary gland development and alpha-lactalbumin production in hypophysectomized, pregnant mice. Biol Reprod 40: 517-524.

TOMPERS, D.M., FOREMAN, R.K., WANG, Q., KUMANOVA, M. and LABOSKY, P.A. (2005). Foxd3 is required in the trophoblast progenitor cell lineage of the mouse embryo. Dev Bio/285: 126-137.

TREMBLAY, G.B., KUNATH, T., BERGERON, D., LAPOINTE, L., CHAMPIGNY C., BADER, J.A., ROSSANT, J. and GIGUERE, V. (2001a). Diethylstilbestrol regulates trophoblast stem cell differentiation as a ligand of orphan nuclear receptor ERR beta. Genes Dev15: 833-838.

TREMBLAY, K.D., DUNN, N.R. and ROBERTSON, E.J. (2001b). Mouse embryos lacking Smad1 signals display defects in extra-embryonic tissues and germ cell formation. Development 128: 3609-3621.

ULLAH, Z., KOHN, M.J., YAGI, R., VASSILEV, L.T. and DEPAMPHILIS, M.L. (2008). Differentiation of trophoblast stem cells into giant cells is triggered by p57/Kip2 inhibition of CDK1 activity. Genes Dev 22, 3024-3036.

VARMUZA, S., PRIDEAUX, V., KOTHARY, R. and ROSSANT, J. (1988). Polytene chromosomes in mouse trophoblast giant cells. Development 102: 127-134.

VOSS, A.K., THOMAS, T. and GRUSS, P. (2000). Mice lacking HSP90beta fail to 
develop a placental labyrinth. Development 127: 1-11.

WANG, H., XIE, H., SUN, X., TRANGUCH, S., ZHANG, H., JIA, X., WANG, D., DAS, S.K., DESVERGNE, B., WAHLI, W. et al. (2007). Stage-specific integration of maternal and embryonic peroxisome proliferator-activated receptor delta signaling is critical to pregnancy success. J Biol Chem 282: 37770-37782.

WANG, J. and ARMANT, D.R. (2002). Integrin-mediated adhesion and signaling during blastocyst implantation. Cells Tissues Organs 172: 190-201.

WANG, J., MAGER, J., CHEN, Y., SCHNEIDER, E., CROSS, J.C., NAGY, A. and MAGNUSON, T. (2001). Imprinted $X$ inactivation maintained by a mouse Polycomb group gene. Nat Genet 28: 371-375.

WANG, J., MAGER, J., SCHNEDIER, E. and MAGNUSON, T. (2002). The mouse $P c G$ gene eed is required for Hox gene repression and extraembryonic development. Mamm Genome 13: 493-503.

WANG, Y., PENFOLD, S., TANG, X., HATTORI, N., RILEY, P., HARPER, J.W., CROSS, J.C. and TYERS, M. (1999). Deletion of the Cul1 gene in mice causes arrest in early embryogenesis and accumulation of cyclin E. Curr Bio/9: 11911194.

WARE, C.B., HOROWITZ, M.C., RENSHAW, B.R., HUNT, J.S., LIGGITT, D., KOBLAR, S.A., GLINIAK, B.C., MCKENNA, H.J., PAPAYANNOPOULOU, T., THOMA, B. et al. (1995). Targeted disruption of the low-affinity leukemia inhibitory factor receptor gene causes placental, skeletal, neural and metabolic defects and results in perinatal death. Development 121: 1283-1299.

WEILER-GUETTLER, H., AIRD, W.C., RAYBURN, H., HUSAIN, M. and ROSENBERG, R.D. (1996). Developmentally regulated gene expression of thrombomodulin in postimplantation mouse embryos. Development 122: 22712281.

WELSH, A.O. and ENDERS, A.C. (1987). Trophoblast-decidual cell interactions and establishment of maternal blood circulation in the parietal yolk sac placenta of the rat. Anat Rec 217: 203-219.

WEN, F., TYNAN, J.A., CECENA, G., WILLIAMS, R., MUNERA, J., MAVROTHALASSITIS, G. and OSHIMA, R.G. (2007). Ets2 is required for trophoblast stem cell self-renewal. Dev Biol 312, 284-299.

WENDLING, O., CHAMBON, P. and MARK, M. (1999). Retinoid X receptors are essential for early mouse development and placentogenesis. Proc Natl Acad SCi USA 96: 547-551.

WERLING, U. and SCHORLE, H. (2002). Transcription factor gene AP-2 gamma essential for early murine development. Mol Cell Bio/22: 3149-3156.

WIEMERS, D.O., SHAO, L.J., AIN, R., DAI, G. and SOARES, M.J. (2003). The mouse prolactin gene family locus. Endocrinology 144: 313-325.

WITHINGTON, S.L., SCOTT, A.N., SAUNDERS, D.N., LOPES FLORO, K., PREIS, J.I., MICHALICEK, J., MACLEAN, K., SPARROW, D.B., BARBERA, J.P. and DUNWOODIE, S.L. (2006). Loss of Cited2 affects trophoblast formation and vascularization of the mouse placenta. Dev Bio/294: 67-82.

YAMADA, K., KANDA, H., TANAKA, S., TAKAMATSU, N., SHIBA, T. and ITO, M. (2006). Sox 15 enhances trophoblast giant cell differentiation induced by Hand1 in mouse placenta. Differentiation 74: 212-221.

YAMAGUCHI, M., OGREN, L., KURACHI, H., HIROTA, K., IMAI, T. and TALAMANTES, F. (1995). Opposite effects of transforming growth factor $a$ and epidermal growth factor on mouse placental lactogen I secretion. Proc. Natl. Acad. Sci. USA 92: 2830-2834.

YAMAMOTO, H., FLANNERY, M.L., KUPRIYANOV, S., PEARCE, J., MCKERCHER, S.R., HENKEL, G.W., MAKI, R.A., WERB, Z. and OSHIMA, R.G. (1998). Defective trophoblast function in mice with a targeted mutation of Ets2. Genes Dev. 12: 1315-1326.
YAMAMOTO, T., ROBY, K.F., KWOK, S.C. and SOARES, M.J. (1994). Transcriptional activation of cytochrome P450 side chain cleavage enzyme expression during trophoblast cell differentiation. J. Biol. Chem. 269: 6517-6523.

YAN, J., TANAKA, S., ODA, M., MAKINO, T., OHGANE, J. and SHIOTA, K. (2001). Retinoic acid promotes differentiation of trophoblast stem cells to a giant cell fate. Dev Bio/235: 422-432.

YANG, W., KLAMAN, L.D., CHEN, B., ARAKI, T., HARADA, H., THOMAS, S.M., GEORGE, E.L. and NEEL, B.G. (2006). An Shp2/SFK/Ras/Erk signaling pathway controls trophoblast stem cell survival. Dev Cel/10: 317-327.

YOTSUMOTO, S., SHIMADA, T., CUI, C.Y., NAKASHIMA, H., FUJIWARA, H. and KO, M.S.H. (1998). Expression of adrenomedullin, a hypotensive peptide, in the trophoblast giant cells at the embryo implantation site in mouse. Dev. Biol. 203: 264-275.

ZHANG, $\mathrm{H}$. and BRADLEY, A. (1996). Mice deficient for BMP2 are nonviable and have defects in amnion/chorion and cardiac development. Development 122, 2977-2986.

ZHANG, J., ZHAO, Y.G., CAO, Y.J., SANG, Q.X. and DUAN, E.K. (2003). Expression and implications of tissue inhibitor of metalloproteinases-4 in mouse embryo. Mol Hum Reprod 9: 143-149.

ZHENG-FISCHHOFER, Q., KIBSCHULL, M., SCHNICHELS, M., KRETZ, M., PETRASCH-PARWEZ, E., STROTMANN, J., REUCHER, H., LYNN, B.D. NAGY, J.I., LYE, S.J. et al. (2007). Characterization of connexin31.1-deficient mice reveals impaired placental development. Dev Bio/312: 258-271.

ZHOU, B., KONG, X. and LINZER, D.I. (2005). Enhanced recovery from thrombocytopenia and neutropenia in mice constitutively expressing a placental hematopoietic cytokine. Endocrinology 146: 64-70.

ZYBINA, E.V., KUDRYAVTSEVA, M.V. and KUDRYAVTSEV, B.N. (1975). Polyploidization and endomitosis in giant cells of rabbit trophoblast. Cell Tissue Res 160: 525-537.

ZYBINA, E.V. and ZYBINA, T.G. (1985). Polyteny and endomitosis in supergiant trophoblast cells of the gray vole Microtus subarvalis. Tsitologiia 27: 402-410.

ZYBINA, E.V. and ZYBINA, T.G. (1996). Polytene chromosomes in mammalian cells. Int. Rev. Cytol. 165: 53-119.

ZYBINA, E.V., ZYBINA, T.G., BOGDANOVA, M.S. and STEIN, G.I. (2005). Wholegenome chromosome distribution during nuclear fragmentation of giant trophoblast cells of Microtus rossiaemeridionalis studied with the use of gonosomal chromatin arrangement. Cell Biol Int 29: 1066-1070.

ZYBINA, E.V., ZYBINA, T.G., ISAKOVA, G.K., KIKNADZE, II and SHTEIN, G.I. (1992). Polyploidy and polyteny in the trophoblast cells of the mink. Tsitologiia 34: 55-59.

ZYBINA, T.G., FRANK, H.G., BIESTERFELD, S. and KAUFMANN, P. (2004). Genome multiplication of extravillous trophoblast cells in human placenta in the course of differentiation and invasion into endometrium and myometrium. II. Mechanisms of polyploidization. Tsitologiia 46: 640-648.

ZYBINA, T.G., KAUFMANN, P., FRANK, H.G., FREED, J., KADYROV, M. and BIESTERFELD, S. (2002). Genome multiplication of extravillous trophoblast cells in human placenta in the course of differentiation and invasion into endometrium and myometrium. I. Dynamics of polyploidization. Tsitologiia 44 1058-1067.

ZYBINA, T.G., ZYBINA, E.V., KIKNADZE, I.I. and ZHELEZOVA, A.I. (2001) Polyploidization in the trophoblast and uterine glandular epithelium of the endotheliochorial placenta of silver fox (Vulpes fulvus Desm.), as revealed by the DNA content. Placenta 22: 490-498. 


\section{Further Related Reading, published previously in the Int. J. Dev. Biol.}

See our recent Special Issue Epigenetics \& Development edited by Saadi Khochbin and Stefan Nonchev at: http://www.ijdb.ehu.es/web/contents.php?vol=53\&issue=2-3

See Special Issue Pattern Formation edited by Michael K. Richardson and Cheng-Ming Chuong at: http://www.ijdb.ehu.es/web/contents. php?vol=53\&issue=5-6

The influence of the intrauterine environment on human placental development Graham J. Burton, Eric Jauniaux and D. Stephen Charnock-Jones Int. J. Dev. Biol. (2010) 54: 303-312 (doi: 10.1387/ijdb.082764gb)

A twist of insight - the role of Twist-family bHLH factors in development Ralston M. Barnes and Anthony B. Firulli Int. J. Dev. Biol. (2009) 53: 909-924

Spatiotemporal expression of the selenoprotein $\mathbf{P}$ genein postimplantational mouse embryos

Se-Ra Lee, Jung-Min Yon, In-Jeoung Baek, Mi-Ra Kim, Chun-Gui Park, Beom-Jun Lee, Young-Won Yun and Sang-Yoon Nam Int. J. Dev. Biol. (2008) 52: 1005-1011

Puzzles of mammalian fertilization - and beyond J. Michael Bedford Int. J. Dev. Biol. (2008) 52: 415-426

An activating mutation in the PDGF receptor-beta causes abnormal morphology in the mouse placenta

Camilla Looman, Tong Sun, Yang Yu, Agata Zieba, Aive Ahgren, Ricardo Feinstein, Henrik Forsberg, Carina Hellberg, Carl-Henrik Heldin, Xiao-Qun Zhang, Karin Forsberg-Nilsson, Nelson Khoo, Reinald Fundele and Rainer Heuchel

Int. J. Dev. Biol. (2007) 51: 361-370

A simple in vivo approach to investigate invasive trophoblast cells Juan A. Arroyo, Toshihiro Konno, Darya C. Khalili and Michael J. Soares Int. J. Dev. Biol. (2005) 49: 977-980

A generalized caspase inhibitor disrupts early mammalian development Zahra Zakeri Richard A. Lockshin, Luis-Miguel Criado-Rodríguez and Carlos Martínez-A Int. J. Dev. Biol. (2005) 49: 43-51

Control of reproduction by Polycomb Group complexes in animals and plants Anne-Elisabeth Guitton and Frederic Berger Int. J. Dev. Biol. (2005) 49: 707-716

Commitment of hematopoietic stem cells in avian and mammalian embryos: an ongoing story

Françoise Dieterlen-Lièvre

Int. J. Dev. Biol. (2005) 49: 125-130

Changes in the placenta and in the rat embryo caused by the demethylating agent 5azacytidine.

M Vlahovic, F Bulic-Jakus, G Juric-Lekic, A Fucic, S Maric and D Serman Int. J. Dev. Biol. (1999) 43: 843-846

Transgenic mice ubiquitously expressing human placental alkaline phosphatase (PLAP): an additional reporter gene for use in tandem with beta-galactosidase (lacZ). M J Skynner, D J Drage, W L Dean, S Turner, D J Watt and N D Allen Int. J. Dev. Biol. (1999) 43: 85-90

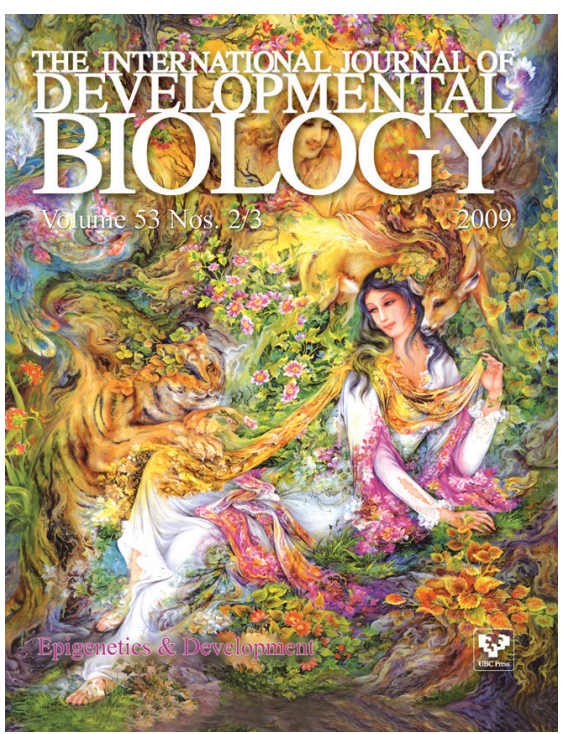

5 yr ISI Impact Factor $(2008)=3.271$

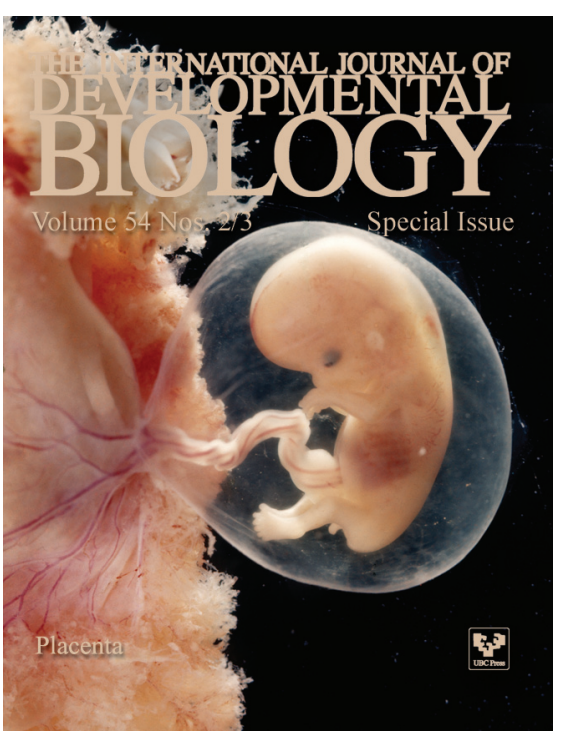

